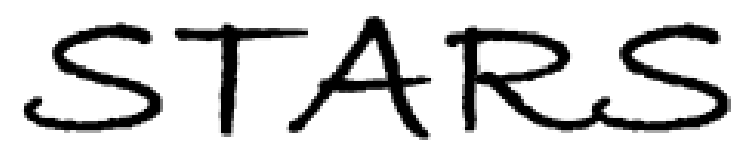

University of Central Florida

STARS

$1-1-2015$

\title{
A Meta-Analysis of Electronic Word-of-Mouth Elasticity
}

Ya You

Gautham G. Vadakkepatt

Amit M. Joshi

University of Central Florida

Find similar works at: https://stars.library.ucf.edu/facultybib2010

University of Central Florida Libraries http://library.ucf.edu

This Article is brought to you for free and open access by the Faculty Bibliography at STARS. It has been accepted for inclusion in Faculty Bibliography 2010 s by an authorized administrator of STARS. For more information, please contactSTARS@ucf.edu.

\section{Recommended Citation}

You, Ya; Vadakkepatt, Gautham G.; and Joshi, Amit M., "A Meta-Analysis of Electronic Word-of-Mouth Elasticity" (2015). Faculty Bibliography 2010s. 6898.

https://stars.library.ucf.edu/facultybib2010/6898

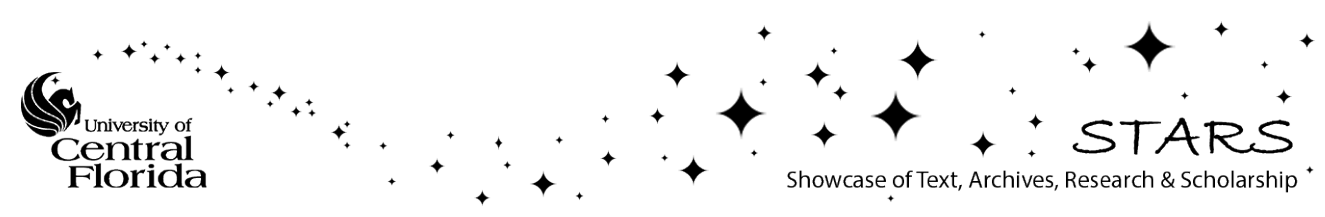




\section{Ya You, Gautham G. Vadakkepatt, \& Amit M. Joshi}

\section{A Meta-Analysis of Electronic Word-of-Mouth Elasticity}

The authors conduct a meta-analysis on the effect of electronic word of mouth on sales by examining 51 studies (involving 339 volume and 271 valence elasticities) and primary data collected on product characteristics (durability, trialability, and usage condition), industry characteristics (industry growth and competition), and platform characteristics (expertise and trustworthiness). Their analysis reveals that electronic word-of-mouth volume (valence) elasticity is .236 (.417). More importantly, the findings show that volume and valence elasticities are higher for privately consumed, low-trialability products that operate in less competitive industries and whose reviews are carried on independent review sites. Furthermore, volume elasticities are higher for durable goods and for reviews on specialized review sites, whereas valence elasticities are greater for community-based sites. Drawing on the results, they discuss several implications for managers and researchers and explain why valence elasticities are often found to be insignificant. Finally, they propose numerous directions for future research in the area on the basis of their findings.

Keywords: electronic word-of-mouth elasticity, social media, meta-analysis

Online Supplement: http://dx.doi.org/10.1509/jm.14.0169

E lectronic word of mouth (eWOM)-Internet-mediated written communications between current or potential consumers (also categorized as consumer-consumer interactions by Yadav and Pavlou [2014]) - has emerged to play an important role in the consumer decision-making process (Cheung and Lee 2012), with an increasing number of consumers trusting these communications over traditional media (Bickart and Schindler 2001; Goldsmith and Horowitz 2006). Not surprisingly, companies are allocating larger portions of their marketing budgets to generate and manage the eWOM process (Moorman 2014). This increased practitioner emphasis on eWOM has resulted in a substantial body of research focused on establishing a link between eWOM and product sales ("eWOM elasticity" hereinafter). Although these studies have advanced our understanding of the effect of eWOM on sales, they also raise several questions. For example, why do we observe such high variances in the reported elasticities (for reported elasticities in each study, see Theme 1 in the Web Appendix) of the two key metrics used to measure eWOM, volume and valence ${ }^{1}$ ? Why,

1 Volume refers to the total number of eWOM messages, and valence refers to the tone or preference of comments (typically expressed as positive/negative/neutral).

Ya You is Assistant Professor of Marketing, School of Business, College of Charleston (e-mail: youy@cofc.edu). Gautham G. Vadakkepatt is Assistant Professor of Marketing, School of Business, George Mason University (e-mail: gradakke@gmu.edu). Amit M. Joshi is Associate Professor of Marketing, College of Business Administration, University of Central Florida (e-mail: Amit.Joshi@ucf.edu). This article is based on the first author's dissertation, and she thanks members of her dissertation committee for their feedback. All authors contributed equally to this research. Roland Rust served as area editor for this article. even when studies focus on the same empirical context, do we observe conflicting findings with regard to these two key metrics? For example, using data from the movie industry, Liu (2006) and Duan, Gu, and Whinston (2008) find that volume, not valence, of consumer reviews is significantly associated with movie revenues, whereas Chintagunta, Gopinath, and Venkataraman (2010) find that it is valence, rather than volume, that drives box office performance. Are all eWOM communications created equal (as most studies assume), or do different platforms (such as blogs, forums, and social networking sites) have varying effects?

To reconcile these issues, to synthesize the research in this domain, and to guide future studies, we undertake a meta-analytic review. More specifically, and as Figure 1 shows, we examine how (1) contextual factors of product, industry, and platform characteristics; (2) strategic action factors of a firm (e.g., advertising, pricing, distribution) ${ }^{2}$; (3) data characteristics; (4) omitted variables; (5) model characteristics; and (6) manuscript status (Albers, Mantrala, and Sridhar 2010; Assmus, Farley, and Lehmann 1984; Sethuraman, Tellis, and Briesch 2011) affect eWOM elasticities.

Although Floyd et al. (2014) provide a previous metaanalysis on the impact of online reviews on sales, there are several differences between our study and theirs that merit discussion. First, Floyd et al. restrict their analysis to online product reviews, whereas we consider several additional sources of eWOM, such as blogs, forums, and social net-

2 We only include traditional strategic factors typically used in a meta-analysis. We acknowledge an anonymous reviewer's comment that other strategic factors of a firm, such as its product line decisions, can also influence elasticity. However, we cannot include these factors in the analysis because our analysis is restricted by the focus and data constraints of published research in this area. 


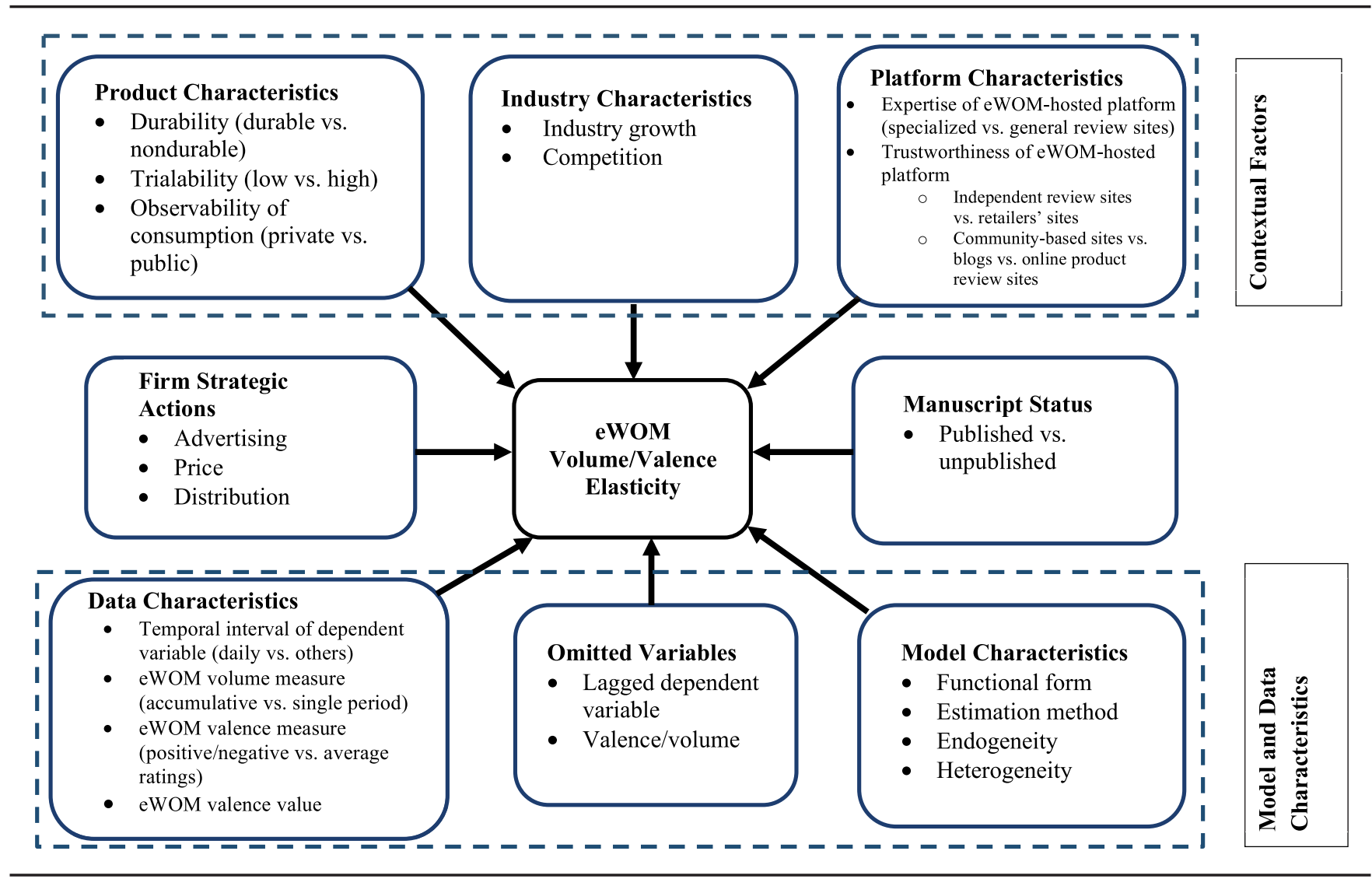

working sites. Consequently, our analysis is more comprehensive, covering 51 studies (with 610 total elasticities), compared with Floyd et al.'s 26 studies and 412 elasticities. More importantly, by considering different sources of eWOM, our research provides a more nuanced understanding of the effect of eWOM platforms on eWOM elasticity because we analyze each platform on the basis of expertise, sender motivation, and sender-recipient relationship. Second, whereas Floyd et al. pool volume and valence elasticities, we analyze each separately. This method enables us to (1) avoid pooling bias, (2) identify unique drivers of volume and valence elasticities, and (3) address conflicts in extant research that pertain to the impact of these dimensions. Third, our research includes multiple new drivers of eWOM elasticity, such as product trialability, industry growth, competition, strategic marketing variables, and numerous data variables that were not considered previously. Perhaps because of these differences, our research overturns some of the findings in Floyd et al. and generates several new results that provide a clearer understanding of the area as well as richer inferences and directions for marketing practice and science alike.

Our meta-analysis of 51 studies involving 339 volume elasticities and 271 valence elasticities (for details on all the studies, products, and platforms included in our analysis, see Themes 1-3 in the Web Appendix) shows the average eWOM volume elasticity to be .236 and the average valence elasticity to be .417 . In general, our results find support for the impact of product, industry, and platform characteristics on eWOM elasticities. When we consider volume and valence elasticities independently, we find many common drivers. For example, we find that privately consumed, low-trialability products that operate in less competitive industries and whose reviews are carried on independent review sites have higher eWOM volume and valence elasticities. Our analysis also reveals certain factors that are significant for only one of the two metrics. For example, we find that platform type (community-based sites vs. blogs vs. online reviews) and failure to consider distribution intensity significantly affect eWOM valence elasticities but not volume elasticities. We also find that data characteristics such as lagged dependent variable and omission of volume/valence metrics in the models have asymmetric effects on eWOM elasticities such that lagged dependent variable and omission of valence (volume) metrics in volume (valence) models significantly affect eWOM volume elasticities but not valence elasticities. By considering valence elasticities separately, we also find that negative ratings (vs. mean rating), rather than positive ratings (vs. mean rating), significantly affect eWOM valence elasticities. Finally, our analysis reveals that interactions between industry growth (product trialability) and valence measures are significant and positive (negative), as is the interaction between industry competition and negative valence measure.

These results also highlight our major contributions. Although we provide a generalizable effect of the two key 
dimensions of eWOM and offer directions for future research, our main contribution is that we resolve the inconsistent findings in previous research and explain heterogeneity in reported elasticities by shedding light on how the contextual factors of product, industry, and platform characteristics influence eWOM elasticity. In doing so, we identify the role of factors such as product trialability, platform type, and industry competition, which were not covered in Floyd et al.'s (2014) previous meta-analysis. Another contribution of our analysis is our evidence that there are some differences between drivers of volume and valence elasticities that scientists and practitioners alike should consider. By analyzing eWOM elasticities separately, we arrived at the key finding that all levels of valence ratings do not affect sales in the same manner. Specifically, we observe that negative ratings have a more significant effect on eWOM valence elasticity. Finally, from the perspective of managers, we find that (1) eWOM elasticities are greater than most other marketing-mix elasticities (with valence elasticities being much larger), (2) managers need to account for product- and industry-specific factors to understand the impact of eWOM volume and valence, and (3) not all eWOM platforms have the same effect.

The remainder of the article is organized as follows. First, we develop hypotheses regarding several factors that could influence eWOM elasticities. Next, we describe the data collection approach and the model we use to test our hypotheses. We then present and discuss the results of our analysis, followed by a discussion of the academic and managerial implications of our findings. We conclude by identifying avenues for future research.

\section{Theory and Hypotheses}

Product uncertainty, defined as a consumer's lack of information about the available alternatives or fit of products with user needs, is a key driver of the extent of information search a consumer undertakes (Maity, Dass, and Malhotra 2014; Moorthy, Ratchford, and Talukdar 1997; Urbany 1986; Urbany, Dickson, and Wilkie 1989). However, this information search is constrained by the cost-benefit tradeoff associated with gathering and processing the information: benefits include reduced product uncertainty, greater fit to user needs, and potential price savings, whereas costs include monetary costs, opportunity cost of time, and the psychological and cognitive costs of gathering and processing the information (e.g., frustration, information overload) (Maity, Dass, and Malhotra 2014; Schmidt and Spreng 1996).

Consumer information search has been studied in-depth in marketing research (e.g., Moorthy, Ratchford, and Talukdar 1997; Srinivasan and Ratchford 1991; Urbany 1986; Urbany, Dickson, and Wilkie 1989). We use this information search literature to develop the conceptual framework of our article for three main reasons. First, for eWOM to affect sales, consumers must seek out this information ${ }^{3}$ and

${ }^{3} \mathrm{We}$ are assuming goal-directed search. However, it is possible that in some contexts, consumers could stumble on this eWOM and then act on the information impulsively. then trust its credibility enough to make decisions based on it. Thus, like any other information source (e.g., traditional advertising), eWOM is subject to the cost-benefit argument in evaluating its usage by consumers and its ultimate effect on sales. Second, prior research has shown that the extent of information sought, the intensity of information search, and the effect of this information on actual purchase behavior can vary according to product characteristics, industry characteristics, and platform characteristics such as credibility of source and message (e.g., Beatty and Smith 1987; Forman, Ghose, and Wiesenfeld 2008; Gu, Park, and Konana 2012; Moore and Lehmann 1980; Urbany 1986; Urbany, Dickson, and Wilkie 1989). Thus, the information search literature provides a rich set of contextual factors to understand their effects on eWOM elasticity. Third, characteristics of the Internet, such as the differing levels of anonymity provided to transmitters of eWOM, enable us to include platform factors that can capture both the enhanced value of that information as well as the costs associated with gathering and processing information online.

In the following subsections, we discuss how the contextual factors of product, industry, and platform characteristics influence eWOM elasticity. For the entire set of expected relationships, see Table 1 .

\section{Product Characteristics}

As we have mentioned, perceived benefits of information search such as reduced product uncertainty and lower prices have a significant impact on search activity (e.g., Schmidt and Spreng 1996; Srinivasan and Ratchford 1991). In this subsection, we argue that the magnitude of these benefits varies according to product characteristics of durability, trialability, and usage situations. Because our explicit assumption is that eWOM metrics affect sales only if consumers first seek out the information, product characteristics influence eWOM elasticity through the extent of information sought through various eWOM platforms.

Product durability (durable vs. nondurable). We expect information search to be more beneficial for durable goods than nondurable goods for two reasons. First, durable goods (e.g., automobiles) are more complex and have longer interpurchase intervals than nondurable goods (e.g., movies) (Farley and Lehmann 1977; Kim and Sullivan 1998; Sethuraman and Tellis 1991). These factors increase the product uncertainty and perceived risk associated with durable goods, which in turn increase the benefits of information search. Consistent with this argument, Moorthy, Ratchford, and Talukdar (1997) find that in the automotive context, the extent of information search depends on relative brand uncertainty (i.e., which brand among the many brands is the best fit) and individual brand uncertainty (i.e., what each brand offers). Second, and mainly because durable goods are more expensive (Urbany 1986), information search for durable goods can also result in larger potential price savings.

Electronic word of mouth is a good source of information because it leverages the advantages of the Internet (i.e., asynchronous mode of communication, multiway communication, communication between potential strangers, and 


\begin{tabular}{|c|c|c|c|}
\hline \multirow[b]{2}{*}{ Variable/Level } & \multicolumn{2}{|c|}{ Expected Sign } & \multirow[b]{2}{*}{ Rationale } \\
\hline & Volume & Valence & \\
\hline \multicolumn{4}{|l|}{ Product Characteristics } \\
\hline $\begin{array}{l}\text { Product durability } \\
\text {-Durable } \\
\text {-Nondurable }\end{array}$ & $(+)$ & $(+)$ & $\begin{array}{l}\text { The eWOM effect is greater for durables than for nondurables. Durable } \\
\text { products are characterized by large interpurchase intervals and high unit } \\
\text { cost; thus, consumers more actively seek information to reduce risk for } \\
\text { durable products. }\end{array}$ \\
\hline $\begin{array}{l}\text { Product trialability } \\
\quad \text { Low } \\
\bullet \text { High }\end{array}$ & $(+)$ & $(+)$ & $\begin{array}{l}\text { The eWOM effect is greater for products with low trialability than for those } \\
\text { with high trialability. For a product with low trialability, a peer consumer's } \\
\text { product experience can serve as a quality signal, which lowers the } \\
\text { perceived risk in the purchase decision-making process. }\end{array}$ \\
\hline $\begin{array}{l}\text { Observability of product } \\
\text { consumption } \\
\text {-Private } \\
\text { •Public }\end{array}$ & $(+)$ & $(+)$ & $\begin{array}{l}\text { The eWOM effect is greater for private products than for public products. } \\
\text { It is more difficult for consumers to infer product quality and fit for use by } \\
\text { learning through observation for products used privately, which thus } \\
\text { motivates consumers to rely on eWOM information. }\end{array}$ \\
\hline \multicolumn{4}{|l|}{ Industry Characteristics } \\
\hline Industry growth & $(+)$ & $(+)$ & $\begin{array}{l}\text { The eWOM effect is greater for industries with greater growth. The lack of } \\
\text { stability of the alternatives available in a growth industry leads consumers } \\
\text { to rely more on eWOM. }\end{array}$ \\
\hline Competition & $(-)$ & $(-)$ & $\begin{array}{l}\text { The eWOM effect is greater for industry with fewer competitors. Increased } \\
\text { competition results in choice overload, which leads to satisficing behavior } \\
\text { and therefore lowers the effectiveness of eWOM. }\end{array}$ \\
\hline $\begin{array}{l}\text { Expertise of eWOM-hosted } \\
\text { platform } \\
\text {-Specialized review sites } \\
\text {-General review sites }\end{array}$ & $(+)$ & $(+)$ & $\begin{array}{l}\text { The eWOM from specialized review sites is more effective than that from } \\
\text { general review sites because it contains product information that is often } \\
\text { more specialized and detailed or considered to reflect the reviewer's higher } \\
\text { level of expertise; thus, it is perceived as more credible to consumers. }\end{array}$ \\
\hline $\begin{array}{l}\text { Trustworthiness of } \\
\text { eWOM-hosted platform } \\
\text { •Independent review sites } \\
\text { •Retailers' sites }\end{array}$ & $(+)$ & $(+)$ & $\begin{array}{l}\text { The eWOM from independent review sites is more effective than that from } \\
\text { retailers' sites. Unlike retailers' sites, independent review sites are not } \\
\text { subject to censoring concerns and are thus perceived as more unbiased } \\
\text { and trustful sources. }\end{array}$ \\
\hline $\begin{array}{l}\text { Trustworthiness of } \\
\text { eWOM-hosted platform } \\
\text {-Community-based sites } \\
\text { •Blogs } \\
\text {-Online product review } \\
\text { sites }\end{array}$ & $(+)$ & $(+)$ & $\begin{array}{l}\text { The eWOM from community-based sites is more effective than that from } \\
\text { blogs and online product review sites because eWOM that is generated } \\
\text { by platforms that encourage participants to reveal their true identity and } \\
\text { develop interconnected networks of relationships is more valuable to } \\
\text { recipients than eWOM that originates from platforms in which users' } \\
\text { identities are anonymous and relationships are not fostered. }\end{array}$ \\
\hline \multicolumn{4}{|l|}{ Firm Action } \\
\hline $\begin{array}{l}\text { Advertising } \\
\cdot \text { Omitted } \\
\cdot \text { Included }\end{array}$ & $(+)$ & $(+)$ & $\begin{array}{l}\text { Increased advertising can stimulate product awareness and eWOM; } \\
\text { increased eWOM can also trigger product awareness and strengthen the } \\
\text { effect of advertising. In addition, more advertising signals a product of } \\
\text { high quality, which may induce high ratings. Because advertising is likely } \\
\text { to be positively related to eWOM volume/valence and sales, we expect } \\
\text { the omission of advertising to induce a positive bias in the eWOM volume/ } \\
\text { valence elasticity. }\end{array}$ \\
\hline $\begin{array}{l}\text { Price } \\
\cdot \text { Omitted } \\
\cdot \text { Included }\end{array}$ & $(+)$ & $(+)$ & $\begin{array}{l}\text { Price may stimulate eWOM (larger number of reviews and higher ratings) } \\
\text { because consumers may enjoy telling others about the low prices they } \\
\text { find or pay and are likely to provide positive reviews about the low price. } \\
\text { Because price is likely to be correlated negatively with eWOM volume/ } \\
\text { valence and sales, we expect the omission of the price variable to bias } \\
\text { the eWOM volume/valence elasticity positively. }\end{array}$ \\
\hline $\begin{array}{l}\text { Distribution } \\
\cdot \text { Omitted } \\
\bullet \text { Included }\end{array}$ & $(+)$ & $(+)$ & $\begin{array}{l}\text { A greater level of product distribution tends to generate herding behavior } \\
\text { among consumers, which leads to increased eWOM. In addition, products } \\
\text { that are anticipated to receive positive reviews are also widely distributed. } \\
\text { Because distribution is likely to be positively correlated to eWOM volume/ } \\
\text { valence and sales, we expect the omission of distribution to bias the eWOM } \\
\text { volume/valence elasticity positively. }\end{array}$ \\
\hline
\end{tabular}


Rationale

\begin{tabular}{l}
\hline Variable/Level \\
\hline Data Characteristics \\
Temporal interval of \\
dependent variable \\
(sales) \\
•Daily \\
•Others \\
eWOM volume measure \\
•Accumulative \\
•Single period \\
\\
•Positive ratings \\
•Negative ratings \\
-Average ratings \\
eWOM valence value
\end{tabular}

\section{Omitted Variables}

Lagged dependent variable -Omitted -Included

Valence/volume -Omitted -Included

\section{Expected Sign}

Volume Valence
We expect that a finer level of temporal aggregation (e.g., daily instead of weekly or monthly) of the dependent variable will positively affect the eWOM volume and valence elasticities because when the dependent variables (e.g., sales) are aggregated at a coarser level, finer fluctuations may be lost.

People tend to weigh recent information more heavily than previous information. Indeed, consumers might not read all reviews because of the opportunity cost of time. Moreover, eWOM tends to fade away more quickly than face-to-face WOM because there is less trust and fewer social interactions in the virtual world. Thus, we expect that the sales response to accumulative eWOM is less than that to single-period (e.g., current/previous time period) eWOM.

We expect the eWOM valence measure of extreme positive ratings (e.g.,

(-) five stars in a 1-5-star rating scale)/extreme negative ratings (e.g., one

(-) star in a 1-5-star rating scale) to negatively bias the valence elasticity because of customer risk aversion.

(-) We expect higher valence ratings to bias the eWOM valence elasticity negatively. The lower the valence ratings, the poorer the product quality perceived, and thus, the stronger effect they have on consumer's decision according to prospect theory.

We expect the omission of lagged sales to positively bias eWOM volume elasticity because lagged sales are likely to be correlated positively with current-period eWOM volume and sales. We have no prior expectations for the effect on valence elasticities.

Valence of ratings tends to trend downward as more reviews accumulate because of self-selection bias. We expect the omission of valence (volume) to bias the eWOM volume (valence) elasticity estimate negatively because valence is likely to be negatively related to volume and positively related to product sales.

\section{Model Characteristics}

Functional form
-Multiplicative
-Others

(?) No prior expectations

Estimation method -OLS

- Others

(?) No prior expectations

Endogeneity
$\cdot$ Omitted
$\cdot$ Included

Heterogeneity

-Omitted

-Included

\section{Other Factors}

Manuscript status

-Published

-Unpublished
Consistent with previous studies (e.g., Bijmolt, Van Heerde, and Pieters 2005; Sethuraman, Tellis, and Briesch 2011), we expect the failure to account for endogeneity to bias the eWOM volume and valence elasticities negatively.

(?) No prior expectations

We expect eWOM volume and valence elasticities in published articles to be greater than those in unpublished articles. 


\begin{tabular}{|c|c|c|c|}
\hline \multirow[b]{2}{*}{ Variable/Level } & \multicolumn{2}{|c|}{ Expected Sign } & \multirow[b]{2}{*}{ Rationale } \\
\hline & Volume & Valence & \\
\hline \multicolumn{4}{|l|}{ Interaction Effects } \\
\hline $\begin{array}{l}\text { eWOM valence measure } \\
\text { (positive vs. average } \\
\text { ratings) } \times \text { Product } \\
\text { trialability (low vs. high) }\end{array}$ & & $(-)$ & $\begin{array}{l}\text { For low-trialability products, extreme positive or negative ratings may } \\
\text { have less influence on eWOM valence elasticities than average ratings } \\
\text { because average ratings can be perceived as the "true" quality of a } \\
\text { product and are used to compare products that cannot be tried before }\end{array}$ \\
\hline $\begin{array}{l}\text { eWOM valence measure } \\
\text { (negative vs. average } \\
\text { ratings) } \times \text { Product } \\
\text { trialability (low vs. high) }\end{array}$ & & $(-)$ & $\begin{array}{l}\text { buying. In contrast, for high-trialability products, average ratings may be } \\
\text { less effective than extreme positive or negative ratings because consumers } \\
\text { may selectively pay attention to the reviews that completely confirm or } \\
\text { disconfirm their own opinions when eWOM serves as a complementary } \\
\text { source to make purchase decision for products easier to try. }\end{array}$ \\
\hline $\begin{array}{l}\text { eWOM valence measure } \\
\text { (positive vs. average } \\
\text { ratings) } \times \text { Observability } \\
\text { of product consumption } \\
\text { (private vs. public) }\end{array}$ & & $(+)$ & \multirow{2}{*}{$\begin{array}{l}\text { For products consumed in a private setting, extreme positive or negative } \\
\text { ratings may have greater influence on eWOM valence elasticities than } \\
\text { average ratings because the product experience is more subjective, } \\
\text { which leads extreme positive or negative ratings to be perceived as } \\
\text { credible in making purchase decisions. However, average ratings would } \\
\text { be more effective than extreme ratings for publicly consumed products } \\
\text { because when people buy those products, they tend to conform to } \\
\text { opinions from the majority of the group (shown by average ratings). }\end{array}$} \\
\hline $\begin{array}{l}\text { eWOM valence measure } \\
\text { (negative vs. average } \\
\text { ratings) } \times \text { Observability } \\
\text { of product consumption } \\
\text { (private vs. public) }\end{array}$ & & $(+)$ & \\
\hline $\begin{array}{l}\text { eWOM valence measure } \\
\text { (positive vs. average } \\
\text { ratings) } \times \text { Industry growth }\end{array}$ & & $(+)$ & \multirow{2}{*}{$\begin{array}{l}\text { For an industry with a higher level of growth, extreme positive or } \\
\text { negative ratings may have greater influence on eWOM valence } \\
\text { elasticities than average ratings because in an environment of frequent } \\
\text { product changes, extreme ratings may be perceived as more informative } \\
\text { for consumer learning than average ratings. }\end{array}$} \\
\hline $\begin{array}{l}\text { eWOM valence measure } \\
\text { (negative vs. average } \\
\text { ratings) } \times \text { Industry growth }\end{array}$ & & $(+)$ & \\
\hline $\begin{array}{l}\text { eWOM valence measure } \\
\text { (positive vs. average } \\
\text { ratings) } \times \text { Competition }\end{array}$ & & $(+)$ & \multirow{2}{*}{$\begin{array}{l}\text { For an industry with increasing competition, extreme positive or negative } \\
\text { ratings may have greater influence on eWOM valence elasticities than } \\
\text { average ratings because when consumers face several competing } \\
\text { products that are difficult to differentiate from one another, extreme } \\
\text { ratings are likely to be more diagnostic and helpful for consumers to } \\
\text { make purchase decisions than average ratings. }\end{array}$} \\
\hline $\begin{array}{l}\text { eWOM valence measure } \\
\text { (negative vs. average } \\
\text { ratings) } \times \text { Competition }\end{array}$ & & $(+)$ & \\
\hline
\end{tabular}

archiving ability) to provide reach, accessibility, and persistence of messages that traditional WOM cannot achieve (Cheung and Lee 2012). Moreover, these Internet platforms make it easier to capture a range of diverse consumer perspectives and better allow consumers to gauge the fit of the product with their own needs and preferences (Chen and Xie 2008). Thus, it is not surprising that recent research on consumer information search in the durable goods context has shown that consumers are switching from offline to online information search (Klein and Ford 2003; Morton, Zettelmeyer, and Silva-Risso 2001; Ratchford, Talukdar, and Lee 2007). In addition, research has shown that searching on the Internet can result in lower prices for consumers of durable goods (Morton, Zettelmeyer, and Silva-Risso 2001; Zettelmeyer, Morton, and Silva-Risso 2006). Because of the greater benefits of information search for durable goods, combined with the benefits of eWOM over traditional WOM, we hypothesize the following:

$\mathrm{H}_{1}$ : Electronic word-of-mouth (a) volume elasticities and (b) valence elasticities are greater for durable products than for nondurable products.
Product trialability (low vs. high). Product trial plays a significant role in influencing consumer beliefs and purchase intentions mostly because it provides a low-risk option through which consumers can more accurately evaluate product attributes and fit (Agarwal and Prasad 1997; Wright and Lynch 1995). In other words, product trials affect sales positively by minimizing product uncertainty (Bawa and Shoemaker 2004). Because product trials provide consumers a cost-effective way to reduce product uncertainty, all else being equal, the benefits of information search for such products are generally lower than for products with low trialability. Therefore, we expect eWOM to have a greater impact on sales for products that have low trialability compared with products that can be easily tried before being purchased. Formally,

\footnotetext{
$\mathrm{H}_{2}$ : Electronic word-of-mouth (a) volume elasticities and (b) valence elasticities are greater for products with low trialability than for products with high trialability.
}

Observability of product consumption (private vs. public). Public consumption of products can weaken the effect of eWOM metrics on sales through three routes. First, 
observing a product in use provides potential consumers with an alternative route to gather information about the product, which in turn reduces the benefits of information obtained through eWOM. Second, observability of product consumption could result in mimicking behavior. Often called observational learning or social learning (Bikhchandani, Hirshleifer, and Welch 1992; Chen, Wang, and Xie 2011), this mimicking behavior could arise because consumers perceive other users' final choice as more reliable information than their own private information (Chen, Wang, and Xie 2011; Dholakia, Basuroy, and Soltysinski 2002). This mimicking behavior, driven by observability of other users' product consumption, can detract from the benefits of information search and therefore weaken eWOM elasticity. Third, products help people not only create self-identities (e.g., Belk 1988; Berger and Heath 2007; Escalas and Bettman 2003) but also infer identities of others (e.g., Belk, Bahn, and Mayer 1982). Thus, products are both extensions of self-identity and part of a person's social identity (Kleine, Kleine, and Kernan 1993). If consumers see a product being used, they may buy the product to conform with others under certain conditions (Schmidt and Spreng 1996), which again reduces the benefits of information obtained through eWOM.

However, products that are privately consumed provide potential consumers with very limited opportunity to learn through observation. For these products, eWOM can have a significant impact on sales by making information from private consumption more readily available, therefore enabling consumers to evaluate whether the product matches their own preferences. Thus, we hypothesize the following:

$\mathrm{H}_{3}$ : Electronic word-of-mouth (a) volume elasticities and (b) valence elasticities are greater for privately consumed products than for publicly consumed products.

The relationship between product observability and eWOM elasticity need not be as clear-cut. This is because it is also possible that consumers engage in more detailed information search for publicly consumed products because of the increased salience of these products in the construction of their self and social identities. According to this argument, publicly consumed goods may benefit from information search, which in turn has implications for eWOM elasticity.

\section{Industry Characteristics}

The number of alternatives available in the marketplace and the stability of these alternatives are important determinants of the extent of information search a consumer undertakes (Beatty and Smith 1987; Moore and Lehmann 1980). In our framework, we consider industry competition as a direct proxy for the number of alternatives in the marketplace, whereas industry growth proxies the stability of the alternatives in the marketplace. We use industry growth to proxy for stability of available alternatives because fast-growth industries are associated with changing technologies, evolving product attributes, and new product introductions, whereas slow-growth industries are associated with stability in products and available alternatives (Klepper 1996; Utterback and Suarez 1993). We expand on these arguments in the following subsections.
Growth. Prior research on industry evolution has provided evidence that growth industries are industries in which (1) the underlying technology is still evolving (Utterback and Suarez 1993) and (2) product innovation, rather than process innovation, is the industry norm (Klepper 1996). These characteristics of growth industries directly correlate with the lack of stability of the alternatives available in a growth industry. Under such market conditions, consumers are less likely to rely on prior knowledge and more likely to rely on externally retrieved information (Hulland and Kleinmuntz 1994; Punj and Staelin 1983). Moreover, the benefits of information search are greater in these contexts. Because eWOM is ubiquitous and is a more credible source of external information (compared with marketing communications) for learning about usage situations and experiences (Bickart and Schindler 2001; Goldsmith and Horowitz 2006), we expect eWOM elasticity to be greater in fast-growth industries.

$\mathrm{H}_{4}$ : Electronic word-of-mouth (a) volume elasticities and (b) valence elasticities are greater for industries with higher growth.

However, the relationship might not be as clear-cut as articulated in $\mathrm{H}_{4}$ for two reasons. First, when the underlying technology or product attributes are changing, the potential for information overload through eWOM increases, which might result in an opposite effect on eWOM elasticity. Second, prior research has shown that the addition of a novel product attribute may result in consumers evaluating the new product poorly because of associated learning costs (Mukherjee and Hoyer 2001), thus negatively affecting sales or at least dampening the eWOM elasticity.

Competition. As the number of competitors in an industry increases, so does the number of options available to a consumer. Although this greater number of options can be beneficial to consumers, it may also result in less information search (Jacoby, Speller, and Kohn 1974; Maity, Dass, and Malhotra 2014): consumers have limited information processing capabilities, and when confronted with numerous options, they may undertake a satisficing strategy (Simon 1955). Relatedly, a greater number of options also increases the cost of information search, mostly through the heightened psychological and cognitive costs associated with searching across and processing these options (Maity, Dass, and Malhotra 2014; Schmidt and Spreng 1996). Consistent with this information search cost reasoning, the choice overload literature (e.g., Botti and Iyengar 2006; Chernev 2003; Iyengar and Lepper 2000) has shown that purchase likelihood decreases in these contexts (e.g., Iyengar and Lepper 2000), as does consumers' confidence in these decisions, especially if they have not articulated their preferences (e.g., Chernev 2003). This decreased confidence could potentially result in consumers delaying their purchase decisions. These arguments lead us to hypothesize the following:

\footnotetext{
$\mathrm{H}_{5}$ : Electronic word-of-mouth (a) volume elasticities and (b) valence elasticities are greater for industries with lower competition.
} 


\section{Platform Characteristics}

For consumers to rely on eWOM rather than other sources of information, there must be some credibility associated with the source of the recommendation. According to Kelman (1961), credibility is composed of two major dimensions, expertise and trustworthiness, in which expertise is defined as the perceived ability of an information source to provide detailed information and trustworthiness is the perceived information source's motivation to make valid assertions without bias (McGuire 1969). Next, we hypothesize how these two dimensions of platform credibility affect eWOM volume and valence elasticities.

Expertise of the eWOM-hosted platform (specialized vs. general review sites). We operationalize expertise by distinguishing specialized review sites, which have a narrow focus on a particular product category (e.g., Flixster.com for movies, CarandDriver.com for cars), and general review sites, which elicit consumer reviews for a wide range of products (e.g., Amazon.com, Epinions.com). Specialized review sites, by their nature, host reviews by experts on that particular product category, whereas generalist platforms may attract more novice reviewers. As such, reviews on specialized review sites have a greater discussion of product attributes, while other consumer reviews may have more information about individual consumer preferences and experiences (Chen and Xie 2005, 2008). Because potential consumers value reviewer expertise (Bansal and Voyer 2000) and because experts evaluate a product on a larger number of attributes (Moorthy, Ratchford, and Talukdar 1997), specialized review sites probably provide more reliable and detailed information to consumers, which in turn can reduce product uncertainty. Therefore, we expect specialized review sites to provide greater benefits to consumers and have a greater effect on eWOM volume and valence elasticities. Formally, we hypothesize the following:

$\mathrm{H}_{6}$ : Electronic word-of-mouth (a) volume elasticities and (b) valence elasticities estimated with reviews from specialized review sites are greater than those estimated with reviews from general review sites.

Trustworthiness of the eWOM-hosted platform. Because traditional WOM is propagated through in-person communication between relatives and friends, it is notably different from eWOM in two ways. First, traditional WOM communication is typically not driven by profit motives. This is one reason why a general consumer belief exists that information received from other product users is more trustworthy than company-sponsored communication (Goldsmith and Horowitz 2006). Second, the effectiveness of traditional WOM is predicated on the familiarity between the sender and recipient of the message to assess source credibility and message quality (Brown and Reingen 1987). However, with eWOM, both these factors are called into question. Thus, we examine two factors that can influence perceived trustworthiness of the eWOM communication: (1) motivation for eWOM and (2) facilitating relationships between the sender and the recipient of the message.
Motivation for eWOM (independent review sites vs. retailers' sites). Prior research has hypothesized that WOM is most effective when there is similarity between the source and the recipient and when their incentives are aligned (e.g., Brown and Reingen 1987). Because it is impossible to infer actual motives, we operationalize this variable by categorizing the type of platform that carries eWOM. The platforms that host eWOM information can be broadly categorized into independent review sites (e.g., Epinions.com) and retailers' sites (e.g., Amazon.com). Previous literature has suggested that retailers may have an incentive to manipulate consumer reviews on their sites to generate more sales (Gu, Park, and Konana 2012). In contrast, independent review websites provide more objective information and are not subject to censoring concerns. Therefore, they are perceived as being more unbiased and trustworthy sources and should have a greater influence on consumer decisions (Senecal and Nantel 2004). Formally,

$\mathrm{H}_{7}$ : Electronic word-of-mouth (a) volume elasticities (b) and valence elasticities estimated with reviews on independent review sites are greater than those estimated with reviews on retailers' sites.

Facilitating relationships between sender and recipient of message (community-based sites vs. blogs vs. online product review sites). Brown and Reingen (1987) show that WOM is at its most influential if there is a strong relationship between the sender and the recipient of the message. A key characteristic of eWOM is that there need not exist any relationship between the sender and recipient of the message to the extent that several forms of eWOM are anonymous. This would not be a problem if the platforms were structured to facilitate assessments of message quality by allowing repeated interactions (and therefore learning) between members of the platform. However, platforms vary in this ability to foster relationships between members. Specifically, communitybased sites (e.g., social networking sites) thrive on repeated interactions among members, who are also often known to one another outside cyberspace, which leads to the development of stronger links between them (Yadav et al. 2013). In contrast, online product review sites, with mostly anonymous reviews, typically do not engender relationship building with the source of the eWOM. Blogs lie in the middle of these anchor points: their success depends on building relationships with readers (who may still remain anonymous). Blogs also facilitate repeated interactions by allowing readers to post comments to the blog and allowing the blog author to respond to these postings. We do not expect the relationship-building abilities of blogs to be stronger than those of community-based sites because (1) the frequency of interaction on community-based sites is greater than that of blogs and (2) members in community-based sites are connected to one another because they have been acquainted at some point in time. It is perhaps for this reason that Ratchford, Talukdar, and Lee (2007) find that even within the world of online information search, consumers rely on different sources of information in varying ways.

In summary, we argue that a hierarchy of trustworthiness exists among media carrying eWOM that depends on 
the depth of relationship between participants. In line with this notion, we posit that eWOM generated by platforms that encourage participants to reveal their true identity and develop interconnected networks of relationships is more valuable to recipients than eWOM that originates on platforms in which users' identities are anonymous and relationships are not fostered (e.g., online product review sites). Therefore, we hypothesize the following:

$\mathrm{H}_{8}$ : Electronic word-of-mouth (a) volume elasticities and (b) valence elasticities estimated with community-based sites are greater than those estimated with blogs, which in turn are greater than those estimated with online product review sites.

\section{Data and Methodology}

To create our database, we conducted a thorough search for studies that report eWOM volume and valence elasticity estimates directly, or for which we could calculate elasticities from regression coefficients using appropriate transformations (for details, see Theme 4 in the Web Appendix). The search procedure we adopted was as follows. First, we conducted an issue-by-issue search of relevant publications from major journals in marketing, management, and information systems that typically publish studies pertaining to WOM (specifically, Journal of Marketing, Journal of Marketing Research, Marketing Science, Management Science, Journal of the Academy of Marketing Science, Information Systems Research, Decision Support Systems, MIS Quarterly, Electronic Commerce Research and Applications, Journal of Interactive Marketing, Journal of Retailing, International Journal of Research in Marketing, Journal of Advertising, Journal of Advertising Research, and Marketing Letters). Second, we used keyword searches (e.g., "electronic WOM," "online WOM," "social media," "online reviews") in several electronic databases such as ABI/INFORM, Business Source Premier, Science Direct, and Google Scholar to identify articles that were pertinent to our study. Third, we searched the Web for working papers (e.g., Social Science Citation Index, Social Science Research Network, Marketing Science Institute, key authors' webpages). Fourth, we conducted a search for dissertations in ProQuest Dissertation and Theses database. Fifth, we reviewed the reference lists in all of the previously obtained articles. Finally, we contacted key authors in this field to request unpublished or working papers.

We included articles in the database using two criteria. First, consistent with the scope of previous meta-analyses of marketing instruments (e.g., Assmus, Farley, and Lehmann 1984; Bijmolt, Van Heerde, and Pieters 2005; Sethuraman, Tellis, and Briesch 2011), we restricted our analysis to the elasticities estimated from econometric models. Thus, we exclude studies using experimental and judgmental data such as purchase intention or preferences. Second, we only considered studies in which elasticities are unambiguously reported or derivable from the estimated coefficients in the regression. Specifically, among a total of 339 (271) volume (valence) elasticities, 265 (73) are reported directly in original studies and 74 (198) are derivable from the estimated coefficients in the regression at the variable means. We transformed coefficients into elasticities using the formulas based on Gemmill, Costa-Font, and McGuire (2007) (see Theme 4 in the Web Appendix). However, when we could not calculate the elasticities, we made every effort to contact the authors to get the information necessary to do so. Theme 1 in the Web Appendix lists not only the studies included in our analysis but also the eWOM volume and valence measures in each study, the average volume and valence elasticities for each of these articles, and whether the elasticities were given or had to be obtained through a transformation.

Using our screening criteria, we identified 51 empirical studies, providing 340 eWOM volume elasticities and 271 eWOM valence elasticities. We dropped one eWOM volume elasticity from the data set after conducting outlier analysis. ${ }^{4}$ Thus, our final research database consists of 339 eWOM volume elasticities and 271 valence elasticities reported in 51 studies. The number of studies included compares favorably with several other meta-analyses of different elements of marketing mix, such as Assmus, Farley, and Lehmann (1984; 16 studies of advertising elasticity) and Tellis (1988; 42 studies of price elasticity). The minimum and maximum number of eWOM volume (valence) elasticities reported in a study is 1 (1) and 46 (36), respectively.

Table 2 shows the coding scheme used in our research. Although the coding scheme for variables that are traditionally included in meta-analyses is straightforward, we collected primary data on several variables that were not available from the source articles themselves. Specifically, the articles did not contain product characteristics, industry characteristics, and platform characteristics, so we manually collected these data for each article or model (in cases of articles with multiple product categories).

Following the coding method in Chandy and Tellis (2000) and Srinivasan, Lilien, and Rangaswamy (2006), we used two expert coders to independently code the product and platform characteristics identified in our conceptual framework. We used different measures of reliability, such as Cohen's kappa (= .85 [.9]) and Krippendorff's alpha $(=.85$ [.95]), in addition to the intercoder agreement of .92 (.96) for product (platform) characteristics to ensure a high level of consistency between two independent coders; a third researcher resolved the remaining disagreements. For industry characteristics, we used the historical method to collect data on industry growth and number of competitors (for details, see Theme 5 in the Web Appendix). We obtained other, more traditional influencing factors such as firm actions, data characteristics, omitted variables, model characteristics, and manuscript status directly from each of the individual studies. Table 3 shows the summary statistics, and Theme 6 in the Web Appendix provides correlations of key factors in the eWOM volume and valence models.

\section{Estimation Model and Procedure}

Our analysis proceeds in two stages. First, we perform univariate analyses to obtain estimates of the mean eWOM

${ }^{4}$ Specifically, cook's d, dfits, and boxplot in STATA. Detailed results are available upon request. 
TABLE 2

Factors Included in the Meta-Analysis and Coding Scheme

\begin{tabular}{|c|c|}
\hline Category Variable & Coding Scheme \\
\hline \multicolumn{2}{|l|}{ Product Characteristics } \\
\hline Product durability & $\begin{array}{l}\text { Base: Nondurable } \\
\text { Durable: } 1 \text { (vs. } 0 \text { for not) }\end{array}$ \\
\hline Product trialability & $\begin{array}{l}\text { Base: High } \\
\text { Low: } 1 \text { (vs. } 0 \text { for not) }\end{array}$ \\
\hline Observability of product consumption & $\begin{array}{l}\text { Base: Public } \\
\text { Private: } 1 \text { (vs. } 0 \text { for not) }\end{array}$ \\
\hline \multicolumn{2}{|l|}{ Industry Characteristics } \\
\hline Industry growth & Continuous \\
\hline Competition & Continuous \\
\hline \multicolumn{2}{|l|}{ Platform Characteristics } \\
\hline Expertise of eWOM-hosted platform & $\begin{array}{l}\text { Base: General review sites } \\
\text { Specialized review sites: } 1 \text { (vs. } 0 \text { for not) }\end{array}$ \\
\hline $\begin{array}{l}\text { Trustworthiness of eWOM-hosted platform (eWOM } \\
\text { motivation) }\end{array}$ & $\begin{array}{l}\text { Base: Retailers' sites } \\
\text { Independent review sites: } 1 \text { (vs. } 0 \text { for not) }\end{array}$ \\
\hline $\begin{array}{l}\text { Trustworthiness of eWOM-hosted platform (facilitating } \\
\text { relationships between sender and recipient of message) }\end{array}$ & $\begin{array}{l}\text { Base: Online product review sites } \\
\text { Blogs: } 1 \\
\text { Community-based sites: } 2\end{array}$ \\
\hline \multicolumn{2}{|l|}{ Firm Action } \\
\hline Advertising & Omitted: 1 (vs. 0 for not) \\
\hline Price & Omitted: 1 (vs. 0 for not) \\
\hline Distribution & Omitted: 1 (vs. 0 for not) \\
\hline \multicolumn{2}{|l|}{ Data Characteristics } \\
\hline Temporal interval of dependent variable & $\begin{array}{l}\text { Base: Others } \\
\text { Daily: } 1 \text { (vs. } 0 \text { for not) }\end{array}$ \\
\hline eWOM volume measure & $\begin{array}{l}\text { Base: Single (e.g., current or previous) period } \\
\text { Accumulative: } 1 \text { (vs. } 0 \text { for not) }\end{array}$ \\
\hline $\begin{array}{l}\text { eWOM valence } \\
\text { measure }\end{array}$ & $\begin{array}{l}\text { Base: Average ratings } \\
\text { Positive ratings: } 1 \text { (vs. } 0 \text { for not) } \\
\text { Negative ratings: } 1 \text { (vs. } 0 \text { for not) }\end{array}$ \\
\hline eWOM valence value & Continuous \\
\hline \multicolumn{2}{|l|}{ Omitted Variables } \\
\hline Lagged dependent variable & Omitted: 1 (vs. 0 for not) \\
\hline Valence & Omitted: 1 (vs. 0 for not) \\
\hline Volume & Omitted: 1 (vs. 0 for not) \\
\hline \multicolumn{2}{|l|}{ Model Characteristics } \\
\hline Functional form & $\begin{array}{l}\text { Base: Others } \\
\text { Multiplicative: } 1 \text { (vs. } 0 \text { for not) }\end{array}$ \\
\hline Estimation method & $\begin{array}{l}\text { Base: Others } \\
\text { OLS: } 1 \text { (vs. } 0 \text { for not) }\end{array}$ \\
\hline Endogeneity & Not accounted for: 1 (vs. 0 for accounted for) \\
\hline Heterogeneity & Not accounted for: 1 (vs. 0 for accounted for) \\
\hline \multicolumn{2}{|l|}{ Other Factors } \\
\hline Manuscript status & $\begin{array}{l}\text { Base: Unpublished } \\
\text { Published: } 1 \text { (vs. } 0 \text { for not) }\end{array}$ \\
\hline
\end{tabular}

volume and valence elasticities. We also analyze the distribution of eWOM volume and valence elasticities. Second, we estimate the impact of the aforementioned factors on eWOM volume and valence elasticities. In the context of quantitative meta-analysis, data have a nested or hierarchical structure (i.e., subjects nested within studies; Denson and Seltzer 2011), making traditional regression analyses such as ordinary least squares (OLS) inappropriate because nested data structures may lead to heteroskedasticity in the errors (Krasnikov and Jayachandran 2008). Thus, to account for within-study error correlations between eWOM elasticities, we perform the meta-analysis with hierarchical linear 
TABLE 3

Summary Statistics of Key Variables

\begin{tabular}{|c|c|c|c|c|c|c|c|c|}
\hline \multirow[b]{2}{*}{ Variable } & \multicolumn{4}{|c|}{ eWOM Volume Model ( $\mathrm{N}=339$ ) } & \multicolumn{4}{|c|}{ eWOM Valence Model $(N=271)$} \\
\hline & M & SD & Min & Max & $\mathbf{M}$ & SD & Min & Max \\
\hline \multicolumn{9}{|l|}{ Dependent Variable (DV) } \\
\hline $\begin{array}{l}\text { Volume elasticity } \\
\text { Valence elasticity }\end{array}$ & .236 & .526 & -1.443 & 3.08 & .417 & 1.491 & -5.86 & 7.73 \\
\hline \multicolumn{9}{|l|}{ Independent Variable (IV) } \\
\hline Product durability & .569 & .496 & 0 & 1 & & & & \\
\hline $\begin{array}{l}\text { Product trialability } \\
\text { Observability of product }\end{array}$ & .195 & .397 & 0 & 1 & .269 & .444 & 0 & 1 \\
\hline consumption & .507 & .501 & 0 & 1 & .520 & .501 & 0 & 1 \\
\hline Industry growth & -15.420 & 51.310 & -119 & 140 & .719 & 62.750 & -119 & 140 \\
\hline Competition & 72.540 & 161.240 & 7 & 687 & 81.770 & 151.800 & 7 & 687 \\
\hline $\begin{array}{l}\text { Expertise of eWOM-hosted } \\
\text { platform }\end{array}$ & .381 & .486 & 0 & 1 & & & & \\
\hline $\begin{array}{l}\text { Trustworthiness of } \\
\text { eWOM-hosted platform } \\
\text { (eWOM motivation) }\end{array}$ & .640 & .481 & 0 & 1 & .387 & .488 & 0 & 1 \\
\hline $\begin{array}{l}\text { Trustworthiness of } \\
\text { eWOM-hosted platform } \\
\text { (relationships between } \\
\text { sender and recipient of } \\
\text { message) }\end{array}$ & .378 & .634 & 0 & 2 & .063 & .272 & 0 & 2 \\
\hline Advertising & .602 & .490 & 0 & 1 & .860 & .348 & 0 & 1 \\
\hline Distribution & .652 & .477 & 0 & 1 & .745 & .436 & 0 & 1 \\
\hline Temporal interval of DV & 198 & .399 & 0 & 1 & .314 & .465 & 0 & 1 \\
\hline eWOM volume measure & .475 & .500 & 0 & 1 & & & & \\
\hline eWOM positive ratings & & & & & .177 & .382 & 0 & 1 \\
\hline eWOM negative ratings & & & & & .177 & .382 & 0 & 1 \\
\hline eWOM valence value & & & & & .703 & .175 & .23 & .96 \\
\hline Omitted variable: lagged DV & .690 & .463 & 0 & 1 & .779 & .416 & 0 & 1 \\
\hline Omitted variable: valence & .274 & .447 & 0 & 1 & & & & \\
\hline Omitted variable: volume & & & & & .103 & .305 & 0 & 1 \\
\hline Functional form: multiplicative & e .071 & 257 & 0 & 1 & .092 & .290 & 0 & 1 \\
\hline Estimation method: OLS & .599 & .491 & 0 & 1 & .653 & .477 & 0 & 1 \\
\hline Endogeneity & .307 & .462 & 0 & 1 & .336 & .473 & 0 & 1 \\
\hline Heterogeneity & .324 & .469 & 0 & 1 & .310 & .463 & 0 & 1 \\
\hline Manuscript status & .805 & .397 & 0 & 1 & .882 & .323 & 0 & 1 \\
\hline
\end{tabular}

modeling (HLM), 5 as Bijmolt and Pieters (2001) suggest. Consistent with previous meta-analyses in marketing (e.g., Rubera and Kirca 2012; Troy, Hirunyawipada, and Paswan 2008), we estimate the models using the maximum likelihood estimation method because it produces robust, efficient, and consistent estimates (Hox 2002; Singer and Willet 2003).

The estimated model is as follows:

$$
\begin{gathered}
\text { Level 1: } \mathrm{Y}_{\mathrm{ij}}=\beta_{0 \mathrm{j}}+\beta_{\mathrm{j}} \times \mathrm{X}_{\mathrm{ij}}+\mathrm{e}_{\mathrm{ij}} \text {, and } \\
\text { Level 2: } \beta_{\mathrm{j}}=\gamma_{0}+\mu_{\mathrm{j}},
\end{gathered}
$$

\footnotetext{
5 We estimate the intraclass correlation coefficients $\left(\rho_{1}\right.$ and $\left.\rho_{2}\right)$ for volume and valence models, respectively, which interpret the proportion of within-study variance to the total variance (Raudenbush and Bryk 2001; Snijders and Bosker 1994). In the volume (valence) model, the within-study variance component is significant and equal to .11 (1.04), and the between-studies variance component is significant and equal to $.19(.15)$. Thus, the intraclass correlation coefficient $\rho_{1}$ is .63 (.19/[.19+.11]) and $\rho_{2}$ is .13 $(.15 /[.15+1.04])$, meaning that approximately $63 \%$ and $13 \%$ of the variance is between studies in the volume and valence models, respectively. Therefore, the use of HLM is appropriate in this context (Raudenbush and Bryk 2001).
}

where $\mathrm{Y}_{\mathrm{ij}}$ is the ith eWOM volume (or valence) elasticity from study $\mathrm{j}, \beta_{0 \mathrm{j}}$ is the intercept for the jth study, $\beta_{\mathrm{j}}$ is the parameter estimate of the influencing factors for the jth study, $\mathrm{e}_{\mathrm{ij}}$ is random error associated with ith elasticity in study $\mathrm{j}, \gamma_{0}$ is overall intercept, and $\mu_{\mathrm{j}}$ is the study-level residual error term. The Level 1 equation describes the impact of the contextual, data, and model characteristics previously hypothesized on eWOM volume (or valence) elasticity, which vary at a study level, whereas the Level 2 equation describes the effect of study characteristics on the intercept and slopes in the Level 1 equation.

\section{Robustness Checks}

Before estimating an HLM, we conducted several checks to ensure the robustness of this meta-analysis. First, we examined the bivariate correlations among the potential factors in both volume and valence models and found that some correlations were greater than .7, indicating potential collinearity problems (Ofir and Khuri 1986). Specifically, in the valence model, the correlations between product durability and omission of marketing-mix variables were 
very high (ranging from .5 for omission of advertising to .8 for omission of distribution), leading us to exclude the durability variable. In addition, because the correlation between eWOM platform expertise and trustworthiness (eWOM motivation) was more than .8 in the valence model and the expertise of eWOM platform variable was not significant, we excluded it from further analyses. Furthermore, the omit-price variable had correlations greater than .7 with other variables in the volume and valence models and was insignificant in both models; thus, we also excluded it in the final models.

Second, we considered various plausible interaction effects among product characteristics, industry characteristics, platform characteristics, and eWOM metrics in both volume and valence models. However, due to strong multicollinearity caused by adding certain interaction effects, we could only retain interactions between eWOM valence measures and product or industry characteristics in the final valence model; we had to drop all interaction terms from the volume model. Furthermore, we applied the residual centering procedure (e.g., De Jong, De Ruyter, and Wetzels 2005; Hennig-Thurau, Houston, and Heitjans 2009; Lance 1988) to rule out any remaining collinearity potentially caused by adding interaction terms in the valence model. An inspection of the final models' variance inflation factors (4.5 in the volume model and 3.8 in the valence model) indicates that multicollinearity is not a problem in our analyses. ${ }^{6}$

Third, we applied several methods to check the stability of our results in the final volume and valence models. Only 10 (3) of 171 (171) correlations between key factors in the volume (valence) model were greater than .5 , and no correlation was greater than .7. We performed sensitivity analyses by omitting each of the factors with at least one correlation greater than .5 , one at a time, as proposed in previous meta-analyses (e.g., Bijmolt, Van Heerde, and Pieters 2005). Doing so did not change our findings. Moreover, we randomly sampled observations from each data set and estimated multiple volume and valence models. The coefficient estimates were stable in all cases in both volume and valence models. ${ }^{7}$

Fourth, we performed a residual analysis of errors to determine whether the assumptions of HLM are satisfied (Hox 2002; Singer and Willett 2003). The residual plot did not show significant violations. ${ }^{8}$ In summary, our extensive robustness checks rule out multicollinearity and ensure the stability of our model and results.

\section{Results and Discussion}

\section{Univariate Analysis of eWOM Elasticity}

In Figure 2, Panels A and B, we present the frequency distributions of the eWOM volume and valence elasticity esti-

\footnotetext{
${ }^{6}$ We thank an anonymous reviewer for leading us to conduct this process.

${ }^{7}$ Detailed results are available upon request.

${ }^{8}$ Detailed results are available upon request.
}

mates, respectively. There are 339 (271) eWOM volume (valence) elasticities with magnitudes ranging from -1.44 $(-5.86)$ to 3.08 (7.73). The overall mean eWOM volume and valence elasticities in our meta-analysis are $.236(\mathrm{Mdn}=$ $.096, \mathrm{SD}=.526)$ and $.417(\mathrm{Mdn}=.147, \mathrm{SD}=1.491)$. There were 15 (25) studies reporting negative volume (valence) elasticities, and these results were usually derived from studies conducted in the context of experiential products (books, music, or movies). In the existing eWOM literature, online consumer reviews can influence product sales through awareness effects of volume, persuasive effects of valence, or both (Duan, Gu, and Whinston 2008; Liu 2006). As the results show, the mean of eWOM valence elasticities is much higher than that of eWOM volume elasticities, which highlights the importance of persuasiveness compared with the informative role of eWOM in changing consumer behavior and market outcomes. Furthermore, as shown in Figure 2, Panels A and B, the distribution of valence elasticities seems closer to normal, whereas the distribution of volume elasticities seems bimodal. Using the HLM model, we analyze the effect of various factors that may drive this observation.

\section{Effects of Influencing Factors}

Effects of contextual factors. Table 4 presents the results of the HLM regression for the meta-analysis. We used two fit statistics to verify model fit: (1) Akaike information criterion (AIC) statistics and (2) deviance ( -2 log-likelihood ratio). The final volume model (model with factors: deviance $=312$, AIC $=357$ ) has a better fit than the null volume model (intercept-only model: deviance $=372, \mathrm{AIC}=$ 379), as does the valence model (model with factors: deviance $=796, \mathrm{AIC}=856$; intercept-only model: deviance $=$ 978, $\mathrm{AIC}=984)$. Consistent with $\mathrm{H}_{1 \mathrm{a}}$, we find that eWOM volume elasticities $(\beta=.523, p<.05)$ are greater for durables than for nondurables. We also find that both eWOM volume and valence elasticities (respectively, $\beta=$ $.414, p<.05 ; \beta=1.602, p<.001)$ are greater for products with low trialability than for those with high trialability, which confirms $\mathrm{H}_{2 \mathrm{a}}$ and $\mathrm{H}_{2 b}$. In addition, our results show that for private (vs. public) goods, eWOM volume elasticities $(\beta=.462, p<.05)$ are higher, as are the valence elasticities $(\beta=1.396, p<.01)$. This finding provides support for $\mathrm{H}_{3 \mathrm{a}}$ and $\mathrm{H}_{3 \mathrm{~b}}$.

Regarding the influence of industry characteristics on eWOM effect, we find that the industry growth has no impact on eWOM volume and valence elasticities, which is contrary to $\mathrm{H}_{4 \mathrm{a}}$ and $\mathrm{H}_{4 \mathrm{~b}}$. However, the results indicate that both eWOM volume and valence elasticities (respectively, $\beta=$ $-.001, p<.01 ; \beta=-.005, p<.001)$ are lower with a greater level of competition, in line with the effects hypothesized in $\mathrm{H}_{5 \mathrm{a}}$ and $\mathrm{H}_{5 \mathrm{~b}}$. Thus, our findings show that information overload, which can be driven by increase in product choices, reduces eWOM elasticity.

With respect to the effect of platform characteristics, we find that eWOM volume elasticities are greater by $.646(p<$ .01) when estimated with reviews on specialized review sites than when estimated with reviews on general review sites, in support of $\mathrm{H}_{6 \mathrm{a}}$. Moreover, consistent with $\mathrm{H}_{7 \mathrm{a}}$ and 
FIGURE 2

Frequency Distribution of eWOM Volume and Valence Elasticities

A: Volume Elasticity

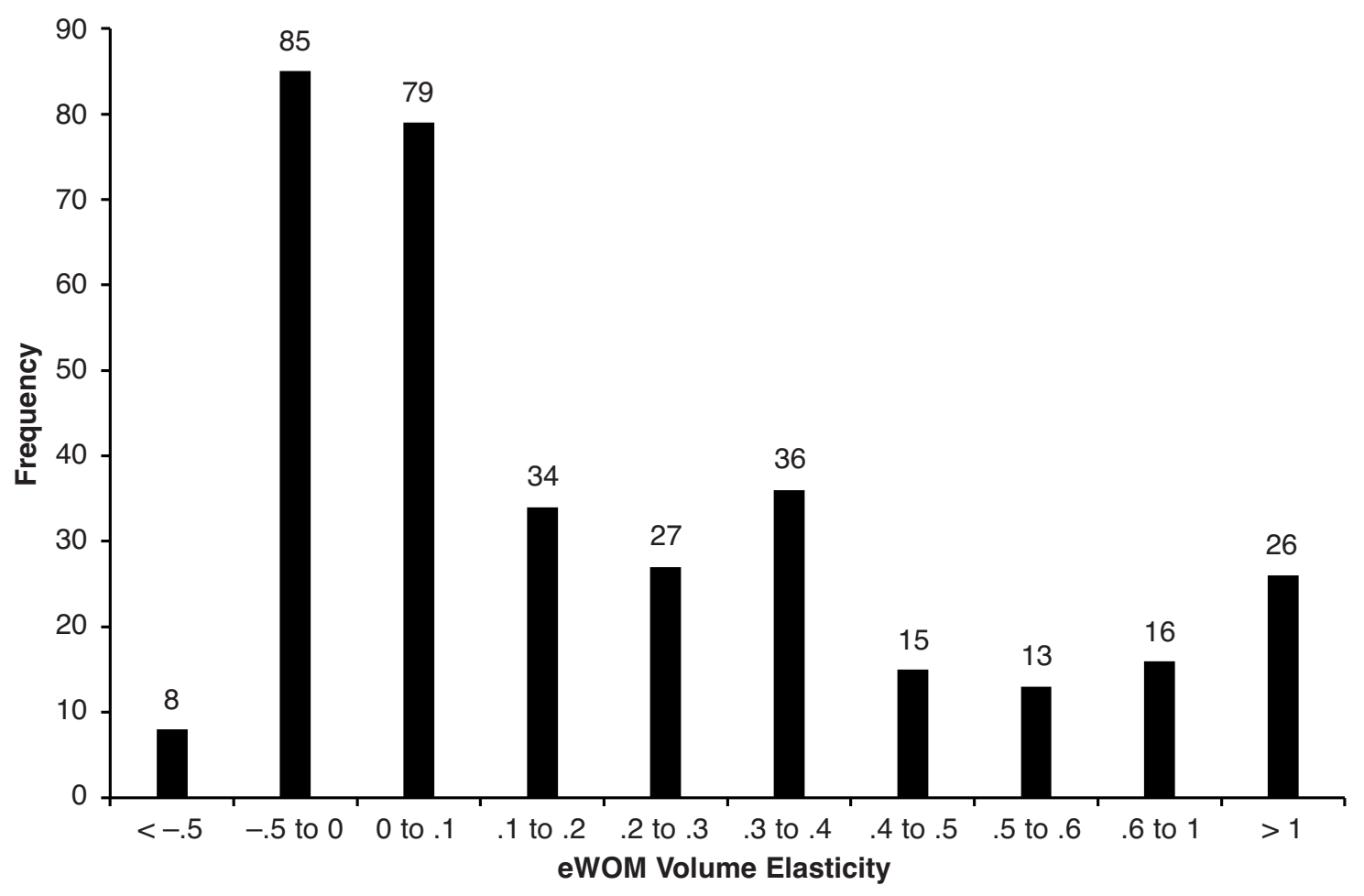

B: Valence Elasticity

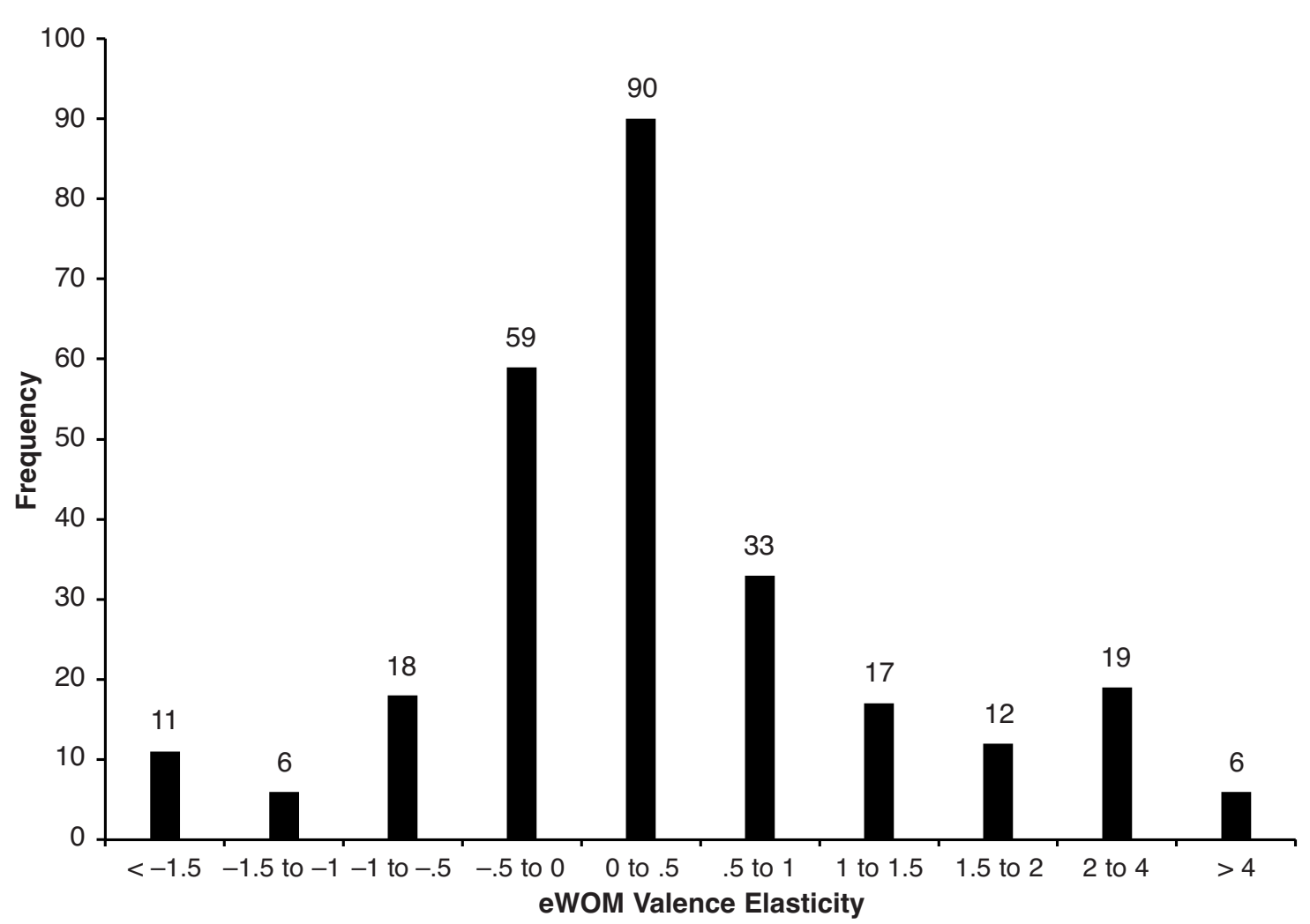


TABLE 4

Estimation Results of HLM

\begin{tabular}{|c|c|c|c|c|c|c|c|c|}
\hline \multirow[b]{2}{*}{ Variable } & \multicolumn{4}{|c|}{ eWOM Volume Elasticity } & \multicolumn{4}{|c|}{ eWOM Valence Elasticity } \\
\hline & Estimate & SE & $p$-Value & $\begin{array}{l}\text { Predicted } \\
\text { Elasticitya }\end{array}$ & Estimate & SE & $p$-Value & $\begin{array}{l}\text { Predicted } \\
\text { Elasticityb }\end{array}$ \\
\hline Constant & -1.361 & .332 & $<.001$ & & -4.330 & .916 & $<.001$ & \\
\hline \multicolumn{9}{|l|}{$\begin{array}{l}\text { Product Characteristics } \\
\text { Product durability }\end{array}$} \\
\hline Nondurable & & & & -.007 & & & & \\
\hline Durable & .523 & .240 & .029 & .516 & & & & \\
\hline \multicolumn{9}{|l|}{ Product trialability } \\
\hline High & & & & .210 & & & & \\
\hline Low & .414 & .206 & .044 & .624 & 1.602 & .454 & $<.001$ & \\
\hline \multicolumn{9}{|l|}{$\begin{array}{l}\text { Observability of product } \\
\text { consumption }\end{array}$} \\
\hline Public & & & & .057 & & & & \\
\hline Private & .462 & .214 & .031 & .519 & 1.396 & .525 & .008 & \\
\hline \multicolumn{9}{|l|}{ Industry Characteristics } \\
\hline Industry growth & -.001 & .002 & .545 & & .0002 & .002 & .937 & \\
\hline Competition & -.001 & .001 & .003 & & -.005 & .001 & $<.001$ & \\
\hline \multicolumn{9}{|l|}{$\begin{array}{l}\text { Platform Characteristics } \\
\text { Expertise of eWOM-hosted } \\
\text { platform }\end{array}$} \\
\hline General review sites & & & & .045 & & & & \\
\hline Specialized review sites & .646 & .208 & .002 & .691 & & & & \\
\hline $\begin{array}{l}\text { Trustworthiness of eWOM- } \\
\text { hosted platform }\end{array}$ & & & & & & & & \\
\hline Retailers' sites & & & & -.026 & & & & .221 \\
\hline Independent review sites & .496 & .193 & .010 & .469 & 2.897 & .389 & $<.001$ & 3.121 \\
\hline $\begin{array}{l}\text { Community-based sites } \\
\text { versus blogs versus online } \\
\text { product review sites }\end{array}$ & .259 & .185 & .161 & & 1.190 & .392 & .002 & \\
\hline \multicolumn{9}{|l|}{ Firm Strategic Action } \\
\hline \multicolumn{9}{|l|}{ Advertising } \\
\hline Included & & & & .165 & & & & .969 \\
\hline Omitted & .210 & .232 & .366 & .375 & .436 & .406 & .284 & 1.405 \\
\hline \multicolumn{9}{|l|}{ Distribution } \\
\hline Included & & & & .365 & & & & .325 \\
\hline Omitted & -.113 & .108 & .296 & .252 & 1.367 & .443 & .002 & 1.692 \\
\hline \multicolumn{9}{|l|}{ Data Characteristics } \\
\hline \multicolumn{9}{|l|}{ Temporal interval of DV } \\
\hline Others & & & & .178 & & & & 1.386 \\
\hline Daily & .573 & .164 & $<.001$ & .751 & -.133 & .346 & .700 & 1.253 \\
\hline \multicolumn{9}{|l|}{ eWOM volume measure } \\
\hline Single period & & & & .296 & & & & \\
\hline Accumulative & -.011 & .132 & .932 & .285 & & & & \\
\hline \multicolumn{9}{|l|}{ eWOM valence measure } \\
\hline Positive ratings & & & & & .179 & .271 & .508 & \\
\hline Negative ratings & & & & & -1.277 & .271 & $<.001$ & \\
\hline eWOM valence value & & & & & 1.148 & .919 & .212 & \\
\hline \multicolumn{9}{|l|}{ Omitted Variables } \\
\hline \multicolumn{9}{|l|}{ Lagged DV } \\
\hline Included & & & & .138 & & & & 1.139 \\
\hline Omitted & .222 & .128 & .083 & .360 & .263 & .258 & .309 & 1.402 \\
\hline \multicolumn{9}{|l|}{ Valence } \\
\hline Included & & & & .405 & & & & \\
\hline Omitted & -.417 & .191 & .029 & -.012 & & & & \\
\hline \multicolumn{9}{|l|}{ Volume } \\
\hline Included & & & & & & & & 1.365 \\
\hline Omitted & & & & & -.196 & .414 & .635 & 1.169 \\
\hline
\end{tabular}


TABLE 4

Continued

\begin{tabular}{|c|c|c|c|c|c|c|c|c|}
\hline \multirow[b]{2}{*}{ Variable } & \multicolumn{4}{|c|}{ eWOM Volume Elasticity } & \multicolumn{4}{|c|}{ eWOM Valence Elasticity } \\
\hline & Estimate & SE & $p$-Value & $\begin{array}{l}\text { Predicted } \\
\text { Elasticitya }\end{array}$ & Estimate & SE & $p$-Value & $\begin{array}{l}\text { Predicted } \\
\text { Elasticityb }\end{array}$ \\
\hline \multicolumn{9}{|l|}{ Model Characteristics } \\
\hline Others & & & & .315 & & & & 1.504 \\
\hline Multiplicative & -.335 & .284 & .237 & -.020 & -1.735 & .657 & .008 & -.231 \\
\hline Estimation method & & & & & & & & \\
\hline Others & & & & .390 & & & & 1.098 \\
\hline OLS & -.165 & .148 & .264 & .225 & .377 & .305 & .216 & 1.475 \\
\hline Endogeneity & & & & & & & & \\
\hline Accounted for & & & & .257 & & & & 1.076 \\
\hline $\begin{array}{l}\text { Not accounted for } \\
\text { Heterogeneity }\end{array}$ & .111 & .113 & .326 & .368 & -.688 & .225 & .002 & .388 \\
\hline Accounted for & & & & .207 & & & & 1.096 \\
\hline Not accounted for & .259 & .163 & .112 & .466 & .800 & .276 & .004 & 1.896 \\
\hline \multicolumn{9}{|l|}{ Other Factors } \\
\hline Unpublished & & & & .051 & & & & .843 \\
\hline Published & .298 & .232 & .199 & .349 & .568 & .391 & 146 & 1.411 \\
\hline \multicolumn{9}{|l|}{ Interaction Effects } \\
\hline $\begin{array}{l}\text { Product trialability } \times \\
\text { Positive ratings }\end{array}$ & & & & & -1.772 & .681 & .009 & .693 \\
\hline $\begin{array}{l}\text { Observability of consumption } \times \\
\text { Positive ratings }\end{array}$ & & & & & -.907 & .654 & .166 & .192 \\
\hline $\begin{array}{l}\text { Industry growth } \times \\
\text { Positive ratings }\end{array}$ & & & & & .013 & .004 & $<.001$ & \\
\hline Competition $\times$ Positive ratings & & & & & .011 & .007 & .119 & \\
\hline $\begin{array}{l}\text { Product trialability } \times \\
\text { Negative ratings }\end{array}$ & & & & & -3.412 & .681 & $<.001$ & -2.456 \\
\hline $\begin{array}{l}\text { Observability of consumption } \times \\
\text { Negative ratings }\end{array}$ & & & & & -.963 & .654 & .141 & -2.957 \\
\hline $\begin{array}{l}\text { Industry growth } x \\
\text { Negative ratings }\end{array}$ & & & & & .021 & .004 & $<.001$ & \\
\hline Competition $\times$ Negative ratings & & & & & .026 & .007 & $<.001$ & \\
\hline
\end{tabular}

aCalculation of predicted elasticities is adapted from Bijmolt, Van Heerde, and Pieters (2005; Table 2).

bPredicted elasticity for interactions in the valence model is provided when both variables take a value of 1 . Detailed results are available upon request.

$\mathrm{H}_{7 \mathrm{~b}}$, we find that both eWOM volume and valence elasticities (respectively, $\beta=.496, p<.05 ; \beta=2.897, p<.001$ ) estimated with reviews on independent review sites are greater than those estimated with reviews on retailers' sites. Furthermore, only valence elasticities are greater for platforms with strengthened consumer relationships $(\beta=1.19, p<$ .01 ), in support of $\mathrm{H}_{8 \mathrm{~b}}$; volume elasticities are insensitive to different platform categories, whether they are communitybased sites, blogs, or online product review sites. This implies that the relationships between message sender and recipient influence the persuasive effect, rather than the awareness effect, of eWOM. In contrast, the awareness effect prevails when products are expensive and complex (i.e., durables) or when reviewer expertise is accounted for (i.e., on specialized review sites).

Effects of other factors. In terms of firm strategic actions, counterintuitively, we do not find any effects on either volume or valence elasticity estimates from the omission of marketing-mix variables, with the exception of (omission of) distribution on the valence elasticity (positive and significant; $\beta=1.367, p<.01)$. We attribute these findings to the nature of the products studied. A large majority of the product categories are associated with uniformly heavy advertising (e.g., cell phones, movies, consumer electronics) and pricing (movies), which may drive this result.

Among data characteristics, our results indicate that the temporal interval of the dependent variable affects eWOM volume elasticities but not valence elasticities. Specifically, eWOM volume elasticity estimates increase by .573 ( $p<$ $.001)$ when estimated with daily rather than weekly or monthly sales data. This is intuitively appealing because several forms of eWOM have a relatively short life cycle, and consumers are more likely to be influenced by what is "trending" than by the qualitative aspects of the conversation (valence).

Notably, the measure of eWOM volume-that is, whether it is cumulative or single period-does not have any effect on volume elasticity estimates. A potential reason for this finding is that eWOM generates a strong carryover 
effect (e.g., Liu 2006; Trusov, Bucklin, and Pauwels 2009), which may negate the recency effect on consumer decision making. The contrast between the impact of aggregation of dependent and independent variables on eWOM elasticities is striking.

Furthermore, we find that models using negative ratings in place of mean ratings are associated with much lower valence elasticities $(\beta=-1.277, p<.001)$. This notable finding may indicate risk aversion by consumers, who react more negatively to bad product reviews. This in turn leads to lower elasticities, an effect that would be masked when using mean ratings.

Our results also show that volume elasticities are positively affected when a lagged dependent variable is omitted but negatively affected when valence information is excluded in the volume models $(\beta=.222, p<.1 ; \beta=-.417$, $p<.05$, respectively). Thus, the inclusion of a lagged dependent variable in eWOM volume models seems necessary to avoid a positive bias, and the inclusion of valence as an explanatory variable is associated with an improvement in volume elasticity estimates. In contrast, the omission of a lagged dependent variable or volume information does not affect estimates of valence elasticities.

With regard to the model characteristics, in general we find that the valence models are more sensitive to issues such as functional form, endogeneity, and heterogeneity adjustment than are volume models. Indeed, we find that volume models are not affected by functional form (multiplicative or others), estimation method (OLS or others), or whether endogeneity or heterogeneity is explicitly accounted for. Valence models, in contrast, tend to produce lower elasticities when estimated with multiplicative models $(\beta=$ $-1.735, p<.01)$ or when endogeneity is not accounted for $(\beta=-.688, p<.01)$, but they produce greater elasticities $(\beta=$ $.8, p<.01)$ when estimated with models without heterogeneity concerns. We find no publication biases in either eWOM volume or valence elasticity estimates.

Finally, we find several notable interaction effects to be significant. Our results show that positive/negative ratings are more impactful in high-growth industries and less impactful for low-trialability products. We find positive interactions between industry growth and both positive and negative ratings (respectively, $\beta=.013, p<.001 ; \beta=.021$, $p<.001)$ and between competition and negative ratings $(\beta=$ $.026, p<.001)$. However, we find negative interactions between product trialability and positive and negative ratings (respectively, $\beta=-1.772, p<.01 ; \beta=-3.412, p<$ $.001)$. Thus, polarized ratings are more impactful in turbulent industries either because they attract consumers from the long tail, especially in online contexts (Brynjolfsson, $\mathrm{Hu}$, and Simester 2011), or because in such conditions, all publicity is good publicity. As indicated previously, most of the studies that find negative elasticities are in the context of the book and movie industries, providing credence to the idea that poor ratings can result in sales, especially because the marginal cost of these products is low. Finally, we find that consumers discount polarized eWOM ratings for products that cannot be tried before consumption. Next, we discuss the various implications of these findings.

\section{Implications and Future Research}

\section{Discussion}

Table 5 provides an overview of our key results. By including separately collected product, industry, and eWOM platform variables in addition to the standard variables used in meta-analysis and then modeling them separately on eWOM volume and valence elasticities, we not only identify important factors driving eWOM elasticities but also arrive at a rich set of academic and managerial implications.

Academic contributions. From an academic perspective, our research makes contributions to both theoretical and empirical approaches used to analyze eWOM effectiveness. From a theoretical perspective, our contributions are threefold. First, we provide a generalized impact of eWOM volume and valence on sales after accounting for a large number of contextual, empirical, and strategic factors. By doing so, we synthesize extant research on eWOM elasticity and also provide a comparison between elasticities of eWOM and other marketing-mix variables (shown in Table 6).

Second, our analysis resolves existing conflicts in this literature on the effectiveness of eWOM valence and volume metrics by identifying product, industry, and platform characteristics that can influence eWOM elasticity. Specifically, and as noted previously, several studies have found either a very small effect or a notable lack of impact of valence on sales (e.g., Duan, Gu, and Whinston 2008; Liu 2006). Our model results demonstrate that valence elasticities will be lower for high-trialability, publicly consumed goods that are rated on retailer sites; they will also be lower when negative ratings are used as an explanatory variable. In addition, valence elasticities are much more sensitive to model and data characteristics, as noted previously. By showing that the effect of eWOM metrics on sales is contingent on product, industry, and platform characteristics, we highlight a more nuanced explanation for observed heterogeneity in eWOM elasticity. Future research (which we discuss in detail subsequently) should expand on the various contingencies that might affect the relationship between these two factors.

Third, we use a cost-benefit of information search argument to develop our hypotheses, thereby providing greater insights into when eWOM volume and valence metrics affect sales. This, combined with our technique of modeling eWOM volume and valence separately, also overturns several findings from the previous meta-analysis (Floyd et al. 2014). Specifically, and in contrast to previous findings, we demonstrate that (1) product durability, trialability, and observability can each affect elasticities; (2) increased competition lowers volume and valence elasticities; (3) the impact of platform variables is asymmetric between eWOM volume and valence elasticities; and (4) the inclusion of negative ratings (vs. average ratings) drastically affects valence models, as do model form, endogeneity, and heterogeneity.

From an empirical analysis perspective, these results also offer several tips for researchers. Capturing the impact of eWOM volume on sales is easier from a modeling perspective because these elasticities are not sensitive to model 
TABLE 5

Key Inferences from Analysis

\begin{tabular}{|c|c|c|c|c|c|c|c|}
\hline \multirow{2}{*}{$\begin{array}{l}\text { Hypo- } \\
\text { thesis }\end{array}$} & \multirow[b]{2}{*}{ Result } & \multirow[b]{2}{*}{ Variable } & \multicolumn{2}{|c|}{ Volume } & \multicolumn{2}{|c|}{ Valence } & \multirow[b]{2}{*}{ Inference } \\
\hline & & & Expected & Actual & Expected & Actual & \\
\hline$\overline{\mathrm{H}_{1}}$ & Confirmed & $\begin{array}{l}\text { Product } \\
\text { durability }\end{array}$ & + & + & + & n.e. ${ }^{a}$ & $\begin{array}{l}\text { The eWOM volume is more effective for } \\
\text { durable goods probably because of the higher } \\
\text { cost associated with a wrong decision. }\end{array}$ \\
\hline $\mathrm{H}_{2}$ & Confirmed & $\begin{array}{l}\text { Product } \\
\text { trialability }\end{array}$ & + & + & + & + & $\begin{array}{l}\text { The eWOM volume and valence are more effec- } \\
\text { tive for a product that has lower trialability proba- } \\
\text { bly because consumers can accurately learn } \\
\text { about the fit of the product with user needs } \\
\text { through trials and do not need to rely on eWOM. }\end{array}$ \\
\hline $\mathrm{H}_{3}$ & Confirmed & $\begin{array}{c}\text { Product } \\
\text { observability }\end{array}$ & + & + & + & + & $\begin{array}{l}\text { Because consumers cannot view the } \\
\text { consumption of products with low observability, } \\
\text { eWOM volume and valence are more effective } \\
\text { for these products. }\end{array}$ \\
\hline $\mathrm{H}_{4}$ & Rejected & $\begin{array}{l}\text { Industry } \\
\text { growth }\end{array}$ & + & n.s. & + & n.s. & $\begin{array}{l}\text { The eWOM volume and valence elasticities are } \\
\text { not affected by industry growth. }\end{array}$ \\
\hline $\mathrm{H}_{5}$ & Confirmed & Competition & - & - & - & - & $\begin{array}{l}\text { The eWOM volume and valence elasticities are } \\
\text { negatively affected by increased competition } \\
\text { probably because choice overload reduces } \\
\text { eWOM elasticities. }\end{array}$ \\
\hline $\mathrm{H}_{6}$ & Confirmed & $\begin{array}{l}\text { Platform } \\
\text { expertise }\end{array}$ & + & + & + & n.e. ${ }^{a}$ & $\begin{array}{l}\text { The eWOM volume elasticities are positively } \\
\text { affected by the perceived expertise of the source } \\
\text { of eWOM because it provides more information } \\
\text { and lends credibility to these communications. }\end{array}$ \\
\hline $\mathrm{H}_{7}$ & Confirmed & $\begin{array}{l}\text { Platform } \\
\text { trust- } \\
\text { worthiness } \\
\text { (eWOM } \\
\text { motivation) }\end{array}$ & + & + & + & + & $\begin{array}{l}\text { The eWOM volume and valence elasticities are } \\
\text { positively affected by the perceived trustworthi- } \\
\text { ness of the platform with altruistic eWOM } \\
\text { motivation because it lends credibility to these } \\
\text { communications. }\end{array}$ \\
\hline $\mathrm{H}_{8}$ & $\begin{array}{l}\text { Partially } \\
\text { confirmed }\end{array}$ & $\begin{array}{l}\text { Platform } \\
\text { trust- } \\
\text { worthiness } \\
\text { (relationships } \\
\text { between } \\
\text { eWOM } \\
\text { sender and } \\
\text { recipient) }\end{array}$ & + & n.s. & + & + & $\begin{array}{l}\text { eWOM valence elasticities are positively } \\
\text { affected by the perceived trustworthiness of the } \\
\text { platform with strengthened relationships } \\
\text { between message sender and recipient } \\
\text { because of inferred credibility from these } \\
\text { relationships on persuasive effect of eWOM. }\end{array}$ \\
\hline
\end{tabular}

aWe were unable to include product durability and platform expertise in the valence model due to multicollinearity.

Notes: n.s. $=$ not significant; n.e. $=$ not estimable.

form, estimation method, or inclusion of endogeneity or heterogeneity, thereby giving researchers a great deal of flexibility in estimating this variable. The robustness of the relationship between eWOM volume and sales is probably one reason that a large number of studies have found only this relationship to be significant. As Tellis (1988) discusses, an appropriate functional form is an empirical issue, and our findings confirm that there is no single best model for eWOM modeling. However, the volume variable may be biased if the lag structure is not properly captured or if valence is not accounted for. In contrast, researchers should exercise caution in using appropriate model form and in accounting for endogeneity or heterogeneity when studying the impact of valence; however, this variable is not affected by lag structure or inclusion of volume as an explanatory variable. Our findings also indicate that eWOM volume elasticity estimates are greater when the dependent variables are at a finer level of aggregation (daily) than a coarser level (weekly or monthly), which is consistent with our expectations. Nevertheless, valence elasticity estimates are not affected by the temporal interval of the dependent variable, which again provides flexibility to researchers who do not have access to finely aggregated data. In addition, the measure of eWOM volume (whether accumulative or single period) does not bias volume elasticities.

Managerial implications. In revisiting Table 6, we demonstrate the importance of eWOM to managers. Of all marketing-mix instruments, eWOM has among the highest short-term elasticities, with the exception of price elasticities (which are fraught with danger for both top-line [Nijs et al. 2001] and bottom-line [Pauwels et al. 2004] metrics). Thus, in eWOM, managers have a powerful tool to influence consumer preferences. We also find that the average volume elasticities are much lower and valence elasticities are higher when a variety of platforms and 
TABLE 6

Comparison with Other Marketing Instrument Elasticities

\begin{tabular}{lll}
\hline Marketing Instruments & \multicolumn{1}{c}{ Article } & \multicolumn{1}{c}{ Mean Elasticity } \\
\hline Advertising elasticities & Assmus, Farley, and Lehmann (1984) & .22 (short-term) \\
& Sethuraman, Tellis, and Briesch (2011) & .41 (long-term) \\
& & .12 (short-term) \\
& Tellis (1988) & .1 .76 \\
Price elasticities & Bijmolt, Van Heerde, and Pieters (2005) & -2.62 \\
Pharmaceutical promotional & Kremer et al. (2008) & .33 (detailing) \\
elasticities & & .12 (direct-to-physician advertising) \\
& & .06 (other direct-to-physician instruments) \\
Personal selling elasticities & Albers, Mantrala, and Sridhar (2010) & .07 (direct-to-consumer advertising) \\
& & .31 (short-term) \\
Online product review elasticities & Floyd et al. (2014) & .69 (volume) \\
& & .35 (valence) \\
eWOM elasticities & Current research & .236 (volume) \\
& & .417 (valence) \\
\hline
\end{tabular}

sources are accounted for, rather than just the online product reviews that Floyd et al. (2014) consider. However, our subsequent analysis shows that practitioners should not ignore industry, platform, and other contextual factors in their calculation of effectiveness of eWOM.

Our study provides clear directions for managers of durable, low-trialability, privately consumed products. Such managers can benefit more from eWOM because both volume and valence elasticities are positively affected for these categories. In general, it can be expected that highinvolvement, experience product categories, for which consumers typically engage in extensive prepurchase information searches, may exhibit greater effectiveness of both eWOM volume and valence.

The analysis of industry characteristics provides further directions for managers. Managers in industries in which competitive pressures are intense should be wary of relying on eWOM alone for generating sales: our results indicate that industry competition is associated with lower elasticities. In contrast, managers in more mature and stable settings (with relatively lower levels of competition) can utilize eWOM as a powerful tool in their marketing mix. More broadly, insofar as these results are driven by advertising share of voice and an expanding and evolving product offering, we would expect that product life cycle may also affect eWOM elasticities. Thus, managers in such volatile environments may be well advised not to overly depend on eWOM to drive sales but to rely more on traditional means of advertising and promotion.

Importantly, we find that the medium is indeed the message, and the type of platform that carries the information has a large impact on its effectiveness. We have argued that the main drivers behind the impact of eWOM are its accessibility and trustworthiness, and these factors are further amplified by the medium. Consumers trust eWOM from neutral, expert-driven third-party sources more, as is reflected in higher elasticities for both volume and valence for information originating from such sites. In addition to highlighting the importance of critics in a wide variety of industries, this finding also explains the popularity of independent, user review-driven sites such as Yelp.com. Thus, we demonstrate that not all social media and eWOM are created equal. We discuss this idea in more detail in the following section.

Intriguingly, our finding that eWOM valence elasticities are lower when negative ratings are included in a model offers a warning for managers: ignoring consumer complaints on the Internet can be a risky proposition. This finding not only explains the growing roles of social media managers and online community managers in organizations but also prompts laggard firms to pay special attention to this aspect of firm-related consumer-to-consumer communication.

\section{Future Research}

Our findings help us generate avenues for future research. We discuss these avenues in the following subsections.

Better understanding of how product characteristics influence eWOM elasticity. In addition to product durability, trialability, and observability identified in our study, several other product characteristics may also influence eWOM elasticity. For example:

-Luxury products versus commodity products. The openness of online platforms might generate more information on luxury brands; alternatively, consumers with high "need for uniqueness" (Cheema and Kaikati 2010) might be reluctant to recommend luxury products, which are purchased for exclusivity and prestige. Future research should provide a more nuanced understanding of whether eWOM has a differential impact on sales of luxury and commodity products and determine which eWOM metric (volume or valence) plays a relatively larger role in generating sales for luxury brands.

-Interaction between product characteristics and consumer search motives. Although our results show that consumers are more responsive to eWOM for durables, we do not directly observe consumer information search behavior. Thus, future studies might explore how product characteristics may inter- 
act with consumer information search motive (prepurchase vs. ongoing search) to affect eWOM effectiveness.

Understanding the effect of environmental characteristics on eWOM elasticity. Our findings indicate that environmental characteristics significantly influence eWOM elasticities. However, we have only scratched the surface with regard to this relationship. The resource dependence perspective (Pfeffer and Salancik 1978) identifies three critical dimensions of any environment that influence performance: munificence (i.e., the industry's ability to accommodate growth of all firms within the industry), dynamism (i.e., unpredictability in the industry), and complexity (i.e., heterogeneity or concentration of resources in the industry; Bahadir, Bharadwaj, and Parzen 2009; Dess and Beard 1984). Industry clock speed (a measure of the rate of innovation in the industry; e.g., Souza, Bayus, and Wagner 2004) and industry advertising intensity (the level of competition on traditional advertising within the industry) are also key operating environment characteristics that can influence firm performance through eWOM generated. Thus, future research could explore the effectiveness of eWOM volume and valence in generating sales in an industry environment that varies in (1) munificence, (2) dynamism, (3) complexity, (4) clock speed, and (5) advertising.

Understanding the effect of eWOM sender and recipient characteristics on eWOM elasticities. Prior research has shown that people differ in their motivation to spread eWOM and to take actions on the basis of eWOM (Zhang, Moe, and Schweidel 2013). We identify two factors that future studies could examine:

-Organic versus incentivized eWOM. Content that consumers feel intrinsically motivated to publish and share on social media is considered organic eWOM, whereas content "encouraged" by firm rewards is called incentivized eWOM. The motives of the eWOM sender may affect how a message is perceived by its recipients and thus may have an impact on eWOM effectiveness. Future research could provide a clear understanding on this topic.

-Recipient heterogeneity. Future studies could investigate how recipient characteristics such as prior knowledge and main- stream product versus niche product preferences influence the effect of eWOM on sales.

Understanding the joint effect of eWOM metrics better. Although most researchers have examined eWOM volume and valence effects independently in previous studies, anecdotal evidence suggests that consumers may evaluate eWOM volume and valence simultaneously and jointly from multiple platforms when making their purchase decisions. Thus, future research could provide a deeper understanding of how eWOM volume and valence may interact with each other across different online platforms to influence consumer purchase behavior.

Understanding the interplay between traditional media and eWOM. Extensive research has been conducted on media synergies (e.g., Naik and Raman 2003) for traditional media, and yet the interplay between advertising and eWOM has been understudied. In particular, very few prior studies distinguish broadcasting and print media. ${ }^{9}$ It would be worthwhile to understand whether there are differences in the effectiveness of traditional media such as broadcasting and print advertising in generating eWOM across online platforms and determine the effectiveness of these advertisements in attracting the right sources of WOM (e.g., early adopters).

\section{Conclusion}

The objectives of this study are (1) to draw insights from the existing literature on eWOM to shed light on the factors that influence eWOM elasticities and (2) to provide implications for researchers and managers and future research avenues in this evolving field. We find that the average eWOM volume (valence) elasticity across the 339 (271) observations is $236(.417)$ and identified a large number of contextual, strategic, and empirical factors that affect these relationships. These findings shed light on whether, how, and under what conditions eWOM works. Our research therefore provides multiple contributions to this important field.

${ }^{9}$ We thank an anonymous reviewer for this suggestion.

\section{REFERENCES 10}

Agarwal, Ritu and Jayesh Prasad (1997), "The Role of Innovation Characteristics and Perceived Voluntariness in the Acceptance of Information Technologies," Decision Sciences, 28 (3), 55782.

Albers, Sonke, Murali K. Mantrala, and Shrihari Sridhar (2010), "Personal Selling Elasticities: A Meta-Analysis," Journal of Marketing Research, 47 (October), 840-53.

Assmus, Gert, John U. Farley, and Donald R. Lehmann (1984), "How Advertising Affects Sales: Meta-Analysis of Econometric Results," Journal of Marketing Research, 21 (February), $65-74$.

Bahadir, S. Cem, Sundar Bharadwaj, and Michael Parzen (2009), "A Meta-Analysis of the Determinants of Organic Sales

${ }^{10}$ Studies included in our meta-analysis data set and used in the body of the article are marked with asterisk $(*)$. For a full set of studies included in our data set, see Theme 1 in the Web Appendix.
Growth," International Journal of Research in Marketing, 26 (4), 263-75.

Bansal, Harvir S. and Peter A. Voyer (2000), "Word-of-Mouth Processes Within a Services Purchase Decision Context," Journal of Service Research, 3 (2), 166-77.

Bawa, Kapil and Robert Shoemaker (2004), "The Effects of Free Sample Promotions on Incremental Brand Sales," Marketing Science, 23 (3), 345-63.

Beatty, Sharon E. and Scott M. Smith (1987), "External Search Effort: An Investigation Across Several Product Categories," Journal of Consumer Research, 14 (1), 83-95.

Belk, Russell (1988), "Possessions and Self," in Wiley International Encyclopedia of Marketing. Hoboken, NJ: John Wiley \& Sons.

— Kenneth D. Bahn, and Robert N. Mayer (1982), "Developmental Recognition of Consumption Symbolism," Journal of Consumer Research, 9 (1), 4-17. 
Berger, Jonah and Chip Heath (2007), "Where Consumers Diverge from Others: Identity Signaling and Product Domains," Journal of Consumer Research, 34 (2), 121-34.

Bickart, Barbara and Robert M. Schindler (2001), "Internet Forums as Influential Sources of Consumer Information," Journal of Interactive Marketing, 15 (3), 31-40.

Bijmolt, Tammo H.A. and Rik G.M. Pieters (2001), "Meta-Analysis in Marketing When Studies Contain Multiple Measurements," Marketing Letters, 12 (2), 157-69.

— , Harald J. van Heerde, and Rik G.M. Pieters (2005), "New Empirical Generalizations on the Determinants of Price Elasticity," Journal of Marketing Research, 42 (May), 141-56.

Bikhchandani, Sushil, David Hirshleifer, and Ivo Welch (1992), "A Theory of Fads, Fashion, Customer, and Cultural Change as Informational Cascades," Journal of Political Economy, 100 (5), 992-1026

Botti, Simona and Sheena S. Iyengar (2006), "The Dark Side of Choice: When Choice Impairs Social Welfare," Journal of Public Policy \& Marketing, 25 (Spring), 24-38.

Brown, Jacqueline Johnson and Peter H. Reingen (1987), "Social Ties and Word-of-Mouth Referral Behavior," Journal of Consumer Research, 14 (3), 350-62.

Brynjolfsson, Erik, Yu Hu, and Duncan Simester (2011), "Goodbye Pareto Principle, Hello Long Tail: The Effect of Search Costs on the Concentration of Product Sales," Management Science, 57 (8), 1373-86.

Chandy, Rajesh K. and Gerard J. Tellis (2000), "The Incumbent's Curse? Incumbency, Size, and Radical Product Innovation," Journal of Marketing, 64 (July), 1-17.

Cheema, Amar and Andrew M. Kaikati (2010), "The Effect of Need for Uniqueness on Word of Mouth," Journal of Marketing Research, 47 (June), 553-63.

*Chen, Yubo, Qi Wang, and Jinhong Xie (2011), "Online Social Interactions: A Natural Experiment on Word of Mouth Versus Observational Learning," Journal of Marketing Research, 48 (April), 238-54.

— and Jinhong Xie (2005), "Third Party Product Review and Firm Marketing Strategy," Marketing Science, 24 (2), 218-40.

- and - (2008), "Online Consumer Review: Word-ofMouth as a New Element of Marketing Communication Mix," Management Science, 54 (3), 477-91.

Chernev, Alexander (2003), "When More Is Less and Less Is More: The Role of Ideal Point Availability and Assortment in Consumer Choice," Journal of Consumer Research, 30 (2), 170-83.

Cheung, Christy M.K. and Matthew K.O. Lee (2012), "What Drives Consumers to Spread Electronic Word of Mouth in Online Consumer-Opinion Platforms," Decision Support Systems, 53 (1), 218-25.

*Chintagunta, Pradeep K., Shyam Gopinath, and Sriram Venkataraman (2010), "The Effects of Online User Reviews on Movie Box Office Performance: Accounting for Sequential Rollout and Aggregation Across Local Markets," Marketing Science, 29 (5), 944-57.

De Jong, Ad, Ko de Ruyter, and Martin Wetzels (2005), "Antecedents and Consequences of Group Potency: A Study of Self-Managing Service Teams," Management Science, 51 (11), 1610-25.

Denson, Nida and Michael H. Seltzer (2011), "Meta-Analysis in Higher Education: An Illustrative Example Using Hierarchical Linear Modeling," Research in Higher Education, 52 (3), 215 44.

Dess, Gregory G. and Donald W. Beard (1984), "Dimensions of Organizational Task Environments," Administrative Science Quarterly, 29 (1), 52-73.

Dholakia, Utpal M., Suman Basuroy, and Kerry Soltysinski (2002), "Auction or Agent (or Both)? A Study of Moderators of the Herding Bias in Digital Auctions," International Journal of Research in Marketing, 19 (2), 115-30.
*Duan, Wenjing, Bin Gu, and Andrew B. Whinston (2008), "The Dynamics of Online Word-of-Mouth and Product Sales - An Empirical Investigation of the Movie Industry," Journal of Retailing, 84 (2), 233-42.

Escalas, Jennifer Edson and James R. Bettman (2003), "You Are What They Eat: The Influence of Reference Groups on Consumers' Connections to Brands," Journal of Consumer Psychology, 13 (3), 339-48.

Farley, John U. and Donald R. Lehmann (1977), "An Overview of Empirical Applications of Buyer Behavior Systems Models," in Advances in Consumer Research, W.D. Perrault, ed. Atlanta: Association for Consumer Research, 337-41.

Floyd, Kristopher, Ryan Freling, Saad Alhoqail, Hyun Young Cho, and Traci Freling (2014), "How Online Product Reviews Affect Retail Sales: A Meta-Analysis," Journal of Retailing, 90 (2), 217-32.

*Forman, Chris, Anindya Ghose, and Batia Wiesenfeld (2008), "Examining the Relationship Between Reviews and Sales: The Role of Reviewer Identity Disclosure in Electronic Markets," Information Systems Research, 19 (3), 291-313.

Gemmill, Marin C., Joan Costa-Font, and Alistair McGuire (2007), "In Search of a Corrected Prescription Drug Elasticity Estimate: A Meta-Regression Approach," Health Economics, 16 (6), 627-43.

Goldsmith, Ronald E. and David Horowitz (2006), "Measuring Motivations for Online Opinion Seeking," Journal of Interactive Advertising , 6 (2), 2-14.

$*^{*} \mathrm{Gu}$, Bin, Jaehong Park, and Prabhudev Konana (2012), "The Impact of External Word-of-Mouth Sources on Retailer Sales for High Involvement Products," Information Systems Research, 23 (1), 182-96.

Hennig-Thurau, Thorsten, Mark B. Houston, and Torsten Heitjans (2009), "Conceptualizing and Measuring the Monetary Value of Brand Extensions: The Case of Motion Pictures," Journal of Marketing, 73 (November), 167-83.

Hox, Joop J. (2002), Multilevel Analysis: Techniques and Application. Mahwah, NJ: Lawrence Erlbaum Associates.

Hulland, John S. and Don N. Kleinmuntz (1994), "Factors Influencing the Use of Internal Summary Evaluations Versus External Information in Choice," Journal of Behavioral Decision Making, 7 (2), 79-102.

Iyengar, Sheena S. and Mark R. Lepper (2000), "When Choice Is Demotivating: Can One Desire Too Much of a Good Thing?" Journal of Personality and Social Psychology, 79 (6), 9951006.

Jacoby, Jacob, Donald E. Speller, and Carol A. Kohn (1974), "Brand Choice Behavior as a Function of Information Load," Journal of Marketing Research, 11 (February), 63-69.

Kelman, H.C. (1961), "Processes of Opinion Change," Public Opinion Quarterly, 25, 57-78.

Kim, Byung-Do and Mary W. Sullivan (1998), "The Effect of Parent Brand Experience on Line Extension Trial and Repeat Purchase," Marketing Letters, 9 (2), 181-93.

Klein, Lisa R. and Gary T. Ford (2003), "Consumer Search for Information in the Digital Age: An Empirical Study of Prepurchase Search for Automobiles," Journal of Interactive Marketing, 17 (3), 29-49.

Kleine, Robert, E., Susan Schultz Kleine, and Jerome B. Kernan (1993), "Mundane Consumption and the Self: A Social-Identity Perspective," Journal of Consumer Psychology, 2 (3), 209235.

Klepper, Steven (1996), "Entry, Exit, Growth, and Innovation over the Product Life Cycle," American Economic Review, 86 (3), 562-83.

Krasnikov, Alexander and Satish Jayachandran (2008), "The Relative Impact of Marketing, Research-and-Development, and Operations Capabilities on Firm Performance," Journal of Marketing, 72 (July), 1-11. 
Kremer, Sara T.M., Tammo H.A. Bijmolt, Peter S.H. Leeflang, and Jaap E. Wieringa (2008), "Generalizations on the Effectiveness of Pharmaceutical Promotional Expenditures," International Journal of Research in Marketing, 25 (4), 234-46.

Lance, Charles E. (1988), "Residual Centering, Exploratory and Confirmatory Moderator Analysis, and Decomposition of Effects in Path Models Containing Interactions," Applied Psychological Measurement, 12 (2), 163-75.

*Liu, Yong (2006), "Word of Mouth for Movies: Its Dynamics and Impact on Box Office Revenue," Journal of Marketing, 70 (July), 74-89.

Maity, Moutusy, Mayukh Dass, and Naresh K. Malhotra (2014), "The Antecedents and Moderators of Offline Information Search: A Meta-Analysis," Journal of Retailing, 90 (2), 233 54.

McGuire, W.J. (1969), "The Nature of Attitudes and Attitude Change," in The Handbook of Social Psychology, 2nd ed., G. Lindzey and E. Aronson, eds. Reading, MA: Addison-Wesley.

Moore, William L. and Donald R. Lehmann (1980), "Individual Differences in Search Behavior for a Nondurable," Journal of Consumer Research, 7 (3), 296-307.

Moorman, Christine (2014), "CMO Survey Report: Highlights and Insights," (August), (accessed January 7, 2015), [available at http://cmosurvey.org/files/2014/09/The_CMO_SurveyHighlights_and_Insights-Aug-2014.pdf].

Moorthy, Sridhar, Brian T. Ratchford, and Debabrata Talukdar (1997), "Consumer Information Search Revisited: Theory and Empirical Analysis," Journal of Consumer Research, 23 (4), 263-77.

Morton, Fiona Scott, Florian Zettelmeyer, and Jorge Silva-Risso (2001), "Internet Car Retailing," Journal of Industrial Economics, 49 (4), 501-519.

Mukherjee, Ashesh and Wayne D. Hoyer (2001), "The Effect of Novel Attributes on Product Evaluation," Journal of Consumer Research, 28 (3), 462-72.

Naik, Prasad A. and Kalyan Raman (2003), "Understanding the Impact of Synergy in Multimedia Communications," Journal of Marketing Research, 40 (November), 375-88.

Nijs, Vincent R., Marnik G. Dekimpe, Jan-Benedict E.M. Steenkamp, and Dominique M. Hanssens (2001), "The CategoryDemand Effects of Price Promotions," Marketing Science, 20 (1), 1-22.

Ofir, Chezy and Andre Khuri (1986), "Multicollinearity in Marketing Models: Diagnostics and Remedial Measures," International Journal of Research in Marketing, 3 (3), 181-205.

Pauwels, Koen, Jorge Silva-Risso, Shuba Srinivasan, and Dominique M. Hanssens (2004), "New Products, Sales Promotions, and Firm Value: The Case of the Automobile Industry," Journal of Marketing, 68 (4), 142-56.

Pfeffer, Jeffrey and Gerald Salancik (1978), The External Control of Organizations: A Resource Dependence Perspective. New York: Harper and Row.

Punj, Girish N. and Richard Staelin (1983), "A Model of Consumer Information Search Behavior for New Automobiles," Journal of Consumer Research, 9 (4), 366-80.

Ratchford, Brian T., Debabrata Talukdar, and Myung-Soo Lee (2007), "The Impact of the Internet on Consumers' Use of Information Sources for Automobiles: A Re-Inquiry," Journal of Consumer Research, 34 (1), 111-19.

Raudenbush, Stephen W. and Anthony S. Bryk (2001), Hierarchical Linear Models: Applications and Data Analysis Methods. Thousand Oaks, CA: Sage Publications.

Rubera, Gaia and Ahmet H. Kirca (2012), "Firm Innovativeness and Its Performance Outcomes: A Meta-Analytic Review and Theoretical Integration," Journal of Marketing, 76 (May), 130-47.
Schmidt, Jeffrey B. and Richard A. Spreng (1996), "A Proposed Model of External Consumer Information Search," Journal of the Academy of Marketing Science, 24 (3), 246-56.

Senecal, Sylvain and Jacques Nantel (2004), "The Influence of Online Product Recommendations on Consumers' Online Choices," Journal of Retailing, 80 (2), 159-69.

Sethuraman, Raj and Gerard J. Tellis (1991), "An Analysis of the Tradeoff Between Advertising and Price Discounting," Journal of Marketing Research, 28 (May), 160-74.

—_ _ - and Richard Briesch (2011), "How Well Does Advertising Work? Generalizations from a Meta-Analysis of Brand Advertising Elasticity," Journal of Marketing Research, 48 (June), 457-71.

Simon, Herbert A. (1955), "A Behavioral Model of Rational Choice," Quarterly Journal of Economics, 69 (1), 99-118.

Singer, Judith D. and John B. Willett (2003), Applied Longitudinal Data Analysis. New York: Oxford University Press.

Snijders, Tom A.B. and Roel J. Bosker (1994), "Modeled Variance in Two-Level Models," Sociological Methods and Research, 22 (3), 342-63.

Souza, Gilvan, Barry L. Bayus, and Harvey M. Wagner (2004), "New-Product Strategy and Industry Clockspeed," Management Science, 50 (4), 537-49.

Srinivasan, Narasimhan and Brian T. Ratchford (1991), "An Empirical Test of a Model of External Search for Automobiles," Journal of Consumer Research, 18 (2), 233-42.

Srinivasan, Raji, Gary L. Lilien, and Arvind Rangaswamy (2006), "The Emergence of Dominant Designs," Journal of Marketing, 70 (April), 1-17.

Tellis, Gerard J. (1988), "The Price Elasticity of Selective Demand: A Meta-Analysis of Econometric Models of Sales," Journal of Marketing Research, 25 (November), 331-41.

Troy, Lisa C., Tanawat Hirunyawipada, and Audhesh K. Paswan (2008), "Cross-Functional Integration and New Product Success: An Empirical Investigation of the Findings," Journal of Marketing, 72 (November), 132-46.

*Trusov, Michael, Randolph E. Bucklin, and Koen Pauwels (2009), "Effects of Word-of-Mouth Versus Traditional Marketing: Findings from an Internet Social Networking Site," Journal of Marketing, 73 (September), 90-102.

Urbany, Joel E (1986), “An Experimental Examination of the Economics of Information," Journal of Consumer Research, 13 (2), 257-71

- , Peter R. Dickson, and William L. Wilkie (1989), "Buyer Uncertainty and Information Search," Journal of Consumer Research, 16 (2), 208-215.

Utterback, James and Fernando F. Suarez (1993), "Innovation, Competition and Industry Structure," Research Policy, 21 (1), $1-21$.

Wright, Alice A. and John G. Lynch Jr. (1995), "Communication Effects of Advertising Versus Direct Experience When Both Search and Experience Attributes Are Present," Journal of Consumer Research, 21 (4), 708-718.

Yadav, Manjit S., Kristine De Valck, Thorsten Hennig-Thurau, Donna L. Hoffman, and Martin Spann (2013), "Social Commerce: A Contingency Framework for Assessing Marketing Potential," Journal of Interactive Marketing, 27 (4), 311-23. - and Paul A. Pavlou (2014), "Marketing in ComputerMediated Environments: Research Synthesis and New Directions," Journal of Marketing, 78 (January), 20-40.

Zettelmeyer, Florian, Fiona Scott Morton, and Jorge Silva-Risso (2006), "How the Internet Lowers Prices: Evidence from Matched Survey and Automobile Transaction Data," Journal of Marketing, 43 (April), 168-81.

Zhang, Yuchi, Wendy W. Moe, and David A. Schweidel (2013), "Drivers of Social Media Rebroadcasting: Investigating the Role of Message Content and Influencers," working paper, Robert H. Smith School of Business, University of Maryland. 